\title{
WHY DEVELOPMENT LEVELS DIFFER: THE SOURCES OF DIFFERENTIAL ECONOMIC GROWTH IN A PANEL OF HIGH AND LOW INCOME COUNTRIES
}

\author{
Charles R. Hulten \\ Anders Isaksson \\ Working Paper 13469 \\ http://www.nber.org/papers/w13469 \\ NATIONAL BUREAU OF ECONOMIC RESEARCH \\ 1050 Massachusetts Avenue \\ Cambridge, MA 02138 \\ October 2007
}

The views expressed in the paper are solely those of the authors and do not necessarily reflect the position of UNIDO or any other organization with which the authors are affiliated. We would like to thank the participants at the NBER Summer Institute 2006, as well as Nobuya Haraguchi, for helpful comments and suggestions. Any remaining errors are our own. The views expressed herein are those of the author(s) and do not necessarily reflect the views of the National Bureau of Economic Research.

(C) 2007 by Charles R. Hulten and Anders Isaksson. All rights reserved. Short sections of text, not to exceed two paragraphs, may be quoted without explicit permission provided that full credit, including (C) notice, is given to the source. 
Why Development Levels Differ: The Sources of Differential Economic Growth in a Panel of High and Low Income Countries

Charles R. Hulten and Anders Isaksson

NBER Working Paper No. 13469

October 2007

JEL No. O11,O47,O57

\begin{abstract}
Average income per capita in the countries of the OECD was more than 20 times larger in 2000 than that of the poorest countries of sub-Sahara Africa and elsewhere, and many of the latter are not only falling behind the world leaders, but have even regressed in recent years. At the same time, other low-income countries have shown the capacity to make dramatic improvements in income per capita. Two general explanations have been offered to account for the observed patterns of growth. One view stresses differences in the efficiency of production are the main source of the observed gap in output per worker. A competing explanation reverses this conclusion and gives primary importance to capital formation. We examine the relative importance of these two factors as an explanation of the gap using 112 countries over the period 1970-2000. We find that differences in the efficiency of production, as measured by relative levels of total factor productivity, are the dominant factor accounting for the difference in development levels. We also find that the gap between rich and most poor nations is likely to persist under prevailing rates of saving and productivity change. To check the robustness of these conclusions, we employ different models of the growth process and different assumptions about the underlying data. Although different models of growth produce different relative contributions of capital formation and TFP, we conclude that the latter is the dominant source of gap. This conclusion must, however, be qualified by the poor quality of data for many developing countries.
\end{abstract}

Charles R. Hulten

Department of Economics

University of Maryland

Room 3105, Tydings Hall

College Park, MD 20742

and NBER

hulten@econ.umd.edu

Anders Isaksson

United Nations Industrial Development Organization

Vienna International Centre

P.O. Box 300

A-1400 Vienna

AUSTRIA

a.isaksson@unido.org 
The question of why economic growth differs among countries question has been asked over and over again, with increasingly better data and ever more sophisticated analytical techniques. ${ }^{1}$ However, the answer remains elusive despite the many advances and growing insights into the problem. Average income per capita in the countries of the OECD was more than 20 times larger in 2000 than that of the poorest countries of sub-Sahara Africa and elsewhere, and many of the latter are not only falling behind the world leaders, but have even regressed in recent years. ${ }^{2}$ At the same time, other low-income countries have shown the capacity to make dramatic improvements in income per capita.

Two general explanations have been offered to account for the observed patterns of growth. One view stresses differences in the efficiency of production are the main source of the observed gap in output per worker, which is the primary determinant of income per capita. At the heart of this view is the idea that improvements in technology and the organization of production lead to higher levels of total factor productivity (TFP) in countries with institutions that support innovation and promote economic efficiency, along with factors like favorable geography, climate, and political stability. Lower levels of TFP are associated with institutions that inhibit or retard innovation and the diffusion of technology, or which have unfavorable environmental factors. In either case, differences in the level of TFP, and not differences in capital formation, largely explain observed differences in income per capita in this view. ${ }^{3}$

\footnotetext{
${ }^{1}$ This question is the organizing theme of the 1998 volume by Landes "The Wealth and Poverty of Nations." Landes examines the historical and institutional context of the income disparities that are so apparent today, and describes many of the theories and perceptions of the accompanied the emergence of this gap. All research on this issue owes a great debt to the pioneering work of Simon Kuznets, both for his historical insights and for his contributions to the development of the national accounting data that make quantitative analysis possible. The sources-of-growth analysis emerged from this effort, greatly advanced by Solow (1957), and applied international growth by Edward F. Denison (1967) and Maddison (1987).

2 These estimates are based on the country groupings shown in the appendix to this paper, and the data on income per capita in derived from the Penn World Tables (Heston, Summers and Aten, 2002).
} 
A competing explanation reverses this conclusion and gives primary importance to capital formation. In this paradigm, capital is defined broadly to include human and knowledge capital, infrastructure systems, as well as the traditional categories of structures and equipment. TFP differences among countries are thought to be extinguished by the rapid diffusion of knowledge, and many papers in this branch of the literature then assume that technology is the same in every country. Some papers also treat technology growth as largely endogenous via investments in knowledge and human capital, and stress the role of externalities. To the extent that institutional differences play a role in explaining the income gap, they tend to be expressed through the rate of capital formation. ${ }^{4}$

The apportionment of the income gap between capital formation and TFP is ultimately an empirical issue. However, this issue has not proved easy to resolve, in part because of parallel disputes about which theoretical models of growth are appropriate, the chief protagonists being endogenous growth theory and neoclassical growth theory. There is also a question of whether it is differences in the rate of growth of output per worker or the corresponding levels that should be explained, and, with respect to the latter, the measurement of the TFP gap using Hicksian versus Harrodian measures of technical change. Not surprisingly, the literature reveals that different assumptions and methods give different results, and one goal of this paper is to examine

\footnotetext{
${ }^{3}$ See Hall and Jones (1999) and Klenow and Rodriguez-Clare (1997) for recent examples of this approach, and for the reviews of the literature. Bosworth and Collins (2003) also provide an extensive survey of recent work in this area, though their own empirical work focuses on rates of growth rather than productivity levels. Contributions to the measurement of international difference in the TFP levels were made by Dowrick and Nguyen (1989), while Färe et al (1994) is an important paper that uses Data Envelopment Analysis to measure technical efficiency (relative to best-practice) among countries. The translog index number approach used in this paper was developed by Jorgenson and Nishimizu (1978), Christensen, Cummings, and Jorgenson (1981), and Caves, Christensen, and Diewert (1982a, 1982b).

${ }^{4}$ This literature is somewhat diverse. It includes Mankiw, Romer, and Weil (1992) and the other papers in what Klenow and Rodriguez-Clare (1997) term the "Neoclassical Revival." See, also, Gollin (2002) for an argument supporting this view. Some of the AK endogenous growth models also fit into this category.
} 
just how large the difference is for a sample of high and low income countries over the period 1970 to 2000 . Our procedure is to decompose the growth rate of output per worker into its TFP and capital-deepening components using competing methods, and compare the results. We follow a similar procedure for the corresponding levels of output per worker, which we also decompose into TFP and capital-deepening components. We then propose a similar decomposition for the Solow steady-state growth model, in order to examine whether the current gap in output per worker between rich and poor countries is likely to persist into the future given current parameters and policies, or whether the process of convergence can be expected to significantly narrow the gap.

The second goal of this paper is to examine the problem of data quality. If there is a dispute about the size of the TFP gap between rich and poor countries, there can be little doubt about the corresponding gap in the data quality. Low-income countries tend to have large nonmarket sectors for which data are problematic or non-existent, and a market sector with a large family business component in which labor income can appear as profit. One result is an implausibly low share of income attributed to labor in national income statistics of these countries: labor's share averages around 30 percent of income in the poorest countries in the sample of this paper, compared to 50 to 60 percent in the richest. Income shares typically serve as proxies for the corresponding output elasticities, which in turn are key determinants of the growth path in most models in the literature (generally, the larger the share of capital, the more important capital formation is relative to TFP as a source of growth). As a result, many researchers reject the published data and either estimate the shares using econometric techniques using the assumption that the shares are constant over time and the same for all countries, or impose an external estimate of the labor and capital shares, typically two-thirds and one-third. 
These procedures essentially imply that every country has a Cobb-Douglas production function, which are identical up to a scalar multiple which is associated with the level of total factor productivity (which is also assumed to be the same for all countries in some formulations). There is a certain irony in this situation, in view the debate over the extent to which the variation in output per worker is due to differences in technology versus differences in capital formation. One objective of this paper is to reexamine the implications of the two-thirds/one-third share rule and robustness of the various growth decompositions to changes in this rule.

\section{Empirical Growth Modeling}

The diverse models in the empirical growth literature share certain common features that can be used to classify and compare them. One core assumption is that the production possibilities of an economy can be characterized by a stable aggregate production function (or a variant of the production function like the cost function or the factor demand equations). Since many of the differences in the literature can be traced to variations on this theme, we will we attempt to organize the various dimensions of the growth debate using this production framework. Since the discussion is largely about fundamentals, we will use a simple graphical exposition adopted by Solow in his seminal paper on the sources of growth.

\section{A. The Aggregate Production Function}

The aggregate production function relates aggregate output $(\mathrm{Y})$ to total inputs of labor $(\mathrm{L})$ and capital (K), with allowance for improvements in the productivity of these inputs. This formulation is so widely used that its implications have become almost invisible in the analysis of growth. However, it is important to acknowledge any analysis based on the aggregate production function asserts, in effect, that the complex technologies of the various firms and sectors that make up an economy can be summarized accurately by a single functional 
representation. The difficulty, here, is that the technical conditions for consistent aggregation are so restrictive as to be intuitively implausible (see, for, example, Fisher $(1965,1969))$. Thus, the use of the aggregate production functions can only be justified as a useful parable for organizing the data in a way that makes economic sense, and as a framework for interpreting empirical results. The debate in the literature over which specification of the aggregation production function is 'factually' appropriate for the analysis of cross-national income differences must therefore be viewed accordingly.

Technical change can be introduced into the aggregate production function in different ways, but the most are variants of the model in which the production function is written as $\mathrm{Y}_{\mathrm{t}}=$ $\mathrm{F}\left(\mathrm{K}_{\mathrm{t}}, \mathrm{L}_{\mathrm{t}}, \mathrm{t}\right)$. The time index $\mathrm{t}$ allows the production function to shift over time in order to capture improvements in the efficiency with which the inputs are used, and 'technical change' is conventionally defined as the partial derivative of $\mathrm{F}\left(\mathrm{K}_{\mathrm{t}}, \mathrm{L}_{\mathrm{t}}, \mathrm{t}\right)$ with respect to $\mathrm{t}$. In the special case in which technical change augments both input proportionately, the production function has the Hick's-neutral form $Y_{t}=A_{t} F\left(K_{t}, L_{t}\right)$. This is the most common form used in empirical growth accounting, following Solow (1957).

Under the assumption of constant returns to scale, the Hicksian production function can be expressed in 'intensive form' as $y_{t}=A_{t} F\left(k_{t}\right)$, with the variables expressed relative to labor: $y_{t}$ $=\mathrm{Y}_{\mathrm{t}} / \mathrm{L}_{\mathrm{t}}$ and $\mathrm{k}_{\mathrm{t}}=\mathrm{K}_{\mathrm{t}} / \mathrm{L}_{\mathrm{t}}$. This form provides an explicit decomposition output per worker, $\mathrm{y}_{\mathrm{t}}$, into the two effects of interest, the level of total factor productivity, $A_{t}$, and the capital-deepening effect, $\mathrm{F}\left(\mathrm{k}_{\mathrm{t}}\right)$. The standard graphical representation of the production model is shown in Figure 1. This figure portrays an economy initially located at the point a on the production function prevailing in that year (1970 in this example). An increase in the efficiency index, from $\mathrm{A}_{70}$ to $\mathrm{A}_{00}$ in the year 2000, causes the production function to shift upward as in the figure. This is 
often associated with the adoption of better technologies over time, but it actually represents a costless improvement in the effectiveness with which capital and labor are used, and it is more appropriately characterized as a change in total factor productivity (TFP). ${ }^{5}$

Output gets a further boost, in Figure 1, from an increase in the capital-labor ratio from $\mathrm{k}_{70}$ to $\mathrm{k}_{00}$. Because of diminishing returns to capital, the production function is shown with a concave shape. Each increment of capital per worker yields a proportionately smaller increase in output per worker. With technology held constant, this increase is represented by the move from point $\underline{a}$ to point $\underline{b}$ on the lower $A_{70}$ branch of the production function. The total change in output per worker in Figure 1 is from $\mathrm{y}_{70}$ to $\mathrm{y}_{00}$, that is, from point a to point $\underline{\mathrm{c}}$, and is the sum of the capital deepening effect, from point $\underline{a}$ to point $\underline{b}$, and the TFP effect, from point $\underline{b}$ to point $\underline{c}$. The relative size of these two effects is the point at issue in the capital versus efficiency controversy, and Figure 1 provides a framework for interpreting and measuring the two effects.

B. Levels versus growth rates

The empirical growth literature provides two ways to implement the intuition of Figure 1, one based on growth rates (growth accounting) and the other on levels (development accounting). The answers can be very different, as the following example illustrates. Suppose that there two economies, $\mathrm{A}$ and $\mathrm{B}$, that both start with the same capital-labor ratio, $\mathrm{k}_{70}$. However, A and B have different levels of output per worker, because they start with different levels of productive efficiency, that is, Economy $\mathrm{A}$ is on the higher of the two production functions in Figure 1 at point $\underline{\mathrm{e}}$, and economy B on the lower one at point $\underline{\mathrm{a}}$. Suppose that, from

\footnotetext{
5 TFP excludes the systematic development of technology paid for by R\&D expenditures, but includes the part resulting from R\&D externalities, learning, or pure inspiration. In addition, it includes changes in organizational efficiency, and institutional factors such as the legal and regulatory environment, geographic location, political stability, as well as deeper cultural attitudes that affect the work place. It also sweeps in all other factors not explicitly included in measured input: omitted variables like infrastructure capital, variations in the utilization of capital and labor (e.g., unemployment), and measurement errors (for further discussion, see Hulten (2001)).
} 
this staring point, both economies only grow by capital deepening, which proceeds at the same rate of growth. They then move along their respective production functions at the same rate, but neither experiences any growth in productivity (neither function shifts). In this example, the entire growth rate in output per worker is due to capital deepening, but all the difference in the level of output per worker is due to the different level of productive efficiency. Moreover, economy B may become richer over time, but will never narrow the gap with economy A.

This simple example illustrates the insufficiency of studying comparative growth rates in isolation from the corresponding levels. Studying comparative levels at a given point in time is also insufficient, since it cannot indicate the growth dynamics and future prospects of the rich and poor countries.

\section{Econometrics versus Nonparametrics}

A number of different estimation procedures have been used in empirical growth analysis. Some studies use an econometric approach in which the production function in Figure 1 is given an explicit functional form and the parameters of that form are estimated. ${ }^{6}$ Flexible functional forms like the translog and generalized-Leontieff forms are common in pure production function studies (or dual cost function and factor demand studies), but are not entirely suitable for the study of low-income countries, which tend to have both inadequate and incomplete data. The Cobb-Douglas form $\mathrm{Y}_{\mathrm{t}}=\mathrm{A}_{\mathrm{t}} \mathrm{K}_{\mathrm{t}}^{\alpha} \mathrm{L}_{\mathrm{t}}^{\beta}$ is often used, either explicitly or implicitly.

Direct estimation of the production function suffers from another well-known problem. The production function is only one equation in a larger system that determines the evolution of

\footnotetext{
6 The specification of the error structure of the production function is also an important issue in the growth and production literature. The common approach is to assume an i.i.d. error structure, which is symmetrically distributed around the production function. An alternative approach is to use a one-sided error term, which then allows the error to be associated with departures from the efficiency frontier.
} 
the system. $K_{t}$ is determined endogenously in the larger system through the savings/investment process, and direct estimation can lead to simultaneous equations bias. The use of instrumental variables is one way to deal with this problem, while another approach is to estimate the reduced form of the growth system. This second option is the used in Mankiw, Romer, and Weil (1992) to estimate the parameters of a Cobb-Douglas function indirectly from the reduced form of the Solow (1956) growth model.

However, both approaches have their drawbacks (e.g., it is difficult to find good instruments) and nonparametric techniques provide an alternative. The two main alternatives are the Solow (1957) growth-accounting model and the Data Envelopment Analysis approach, although the former (as extended by Jorgenson and Griliches (1967)) is much more widely used in the growth analysis. The Solow model provides an accounting framework, based on the Divisia index, in which the growth rate of output per worker $\left(\mathrm{y}_{\mathrm{t}}\right)$ is equal to the growth rate of capital per worker $\left(\mathrm{k}_{\mathrm{t}}\right)$ weighted by capital's income share in GDP, plus a residual factor that accounts for all the remaining growth in $\mathrm{y}_{\mathrm{t}}$ not explained by the weighted growth of $\mathrm{k}_{\mathrm{t}}{ }^{7}$ Solow shows that, under the assumption that prices are equal to marginal costs, the income shares are equal to output elasticities, and the share-weighted growth rate of $\mathrm{k}_{\mathrm{t}}$ is associated with the movement along the production function from $\underline{a}$ to $\underline{b}$ in Figure 1, i.e., with capital deepening, and the residual is associated with the shift in the production from $\underline{b}$ to $\underline{c}$. The Solow sources-ofgrowth decomposition thus provides a method of resolving the growth rate of $\mathrm{y}_{\mathrm{t}}$ into the capitaldeepening effect and the TFP effect.

\footnotetext{
${ }^{7}$ Since accounting data do not come in a continuous time format, the discrete time Törnqvist approximation is typically used in the actual calculations. Growth rates are approximated by the change in the natural logarithms of the variables, weighted by the average income share from one period to the next.
} 
The non-parametric growth accounting approach was extended to the analysis of growth rate to the analysis of the corresponding levels by Jorgenson and Nishimizu (1978), and developed by Caves, Christensen, and Diewert (CCD, 1982a). The CCD model is a Törnqvist index of the level of productivity in each country relative to the average of all countries. It measures the TFP of any country, relative to the average of all countries, by comparing the percentage deviation of $\mathrm{y}_{\mathrm{t}}$ from its international mean with the percentage mean deviation of $\mathrm{k}_{\mathrm{t}}$, weighted by the average of the country's own income share and the international average. Because deviations are computed relative the average of all countries, the frame-of-reference problem implicit in using any one country as the base is avoided. The result is a non-parametric decomposition of the relative gap in $\mathrm{y}_{\mathrm{t}}$ between into its TFP level and capital deepening components, which complement the sources-of-growth rate analysis. ${ }^{8}$

D. Hicks versus Harrod neutrality.

The non-parametric approach also suffers from a form of simultaneous equations bias implicit in the endogeneity of capital. A shift in the production function at a given capital-labor ratio leads to an increase in output per worker and some of this extra output is saved, leading to more output, more saving and so on. In Figure 1, the shift in technology from a to $\underline{\mathrm{e}}$ is the impetus to this effect, and the extra capital induced by the shift is represented by the movement along the upper production function from $\underline{\mathrm{e}}$ to $\underline{\mathrm{c}}$. This is the "induced accumulation effect", and it should be counted as part of TFP, not as exogenous capital formation, in assessing the importance of TFP as a driver of growth (Hulten (1975)).

\footnotetext{
8 The non-parametric and functional form approaches are operationally separate, but Diewert (1976) shows that in order to the Törnquist index to be exact representation of the technology, there must exist an underlying production function of the translog form. This parallels the result by Hulten (1973) that there must be an underlying Hicksian production function in order for the Solow-Jorgenson-Griliches index of total factor productivity to be path independent.
} 
The induced accumulation effect can be captured by measuring the shift in the production function along a constant replacing capital-output ratio, rather than at a constant capital-labor ratio as in the Hicksian case. This idea, which can be traced back to Harrod (1948), is represented in Figure 1 by the movement along the pay from the origin (OP) from a to $\underline{\mathrm{c}}$. It is clear from this figure that all of the growth in output is accounted for by the shift in the production function, measured along the constant $\mathrm{K} / \mathrm{Y}$ ray. However, since the Harrodian gap is measured along a given $\mathrm{K} / \mathrm{Y}$ ratio, it is not a pure measure of the efficiency with which existing resources are used (the normal conception of productivity). Thus, it does not measure a country's distance to the best-practice technology frontier, nor the difference in the technological opportunities separating two countries. It does, however, measure the consequence of a country's move to a higher level of technology.

The situation portrayed along the line OP in Figure 1 is one of balanced growth with Harrod-neutral technical change. We will examine the growth implications of this case in more detail in a subsection that follows, but the measurement implications are worth noting here. Harrod-neutral technical change can be expressed analytically as pure labor-augmenting technical change in the production function $\mathrm{Y}_{\mathrm{t}}=\mathrm{F}\left(\mathrm{K}_{\mathrm{t}}, \mathrm{a}_{\mathrm{t}} \mathrm{L}_{\mathrm{t}}\right)$. This is a restricted form of the more general technology $Y_{t}=F\left(K_{t}, L_{t}, t\right)$, and is a different restriction from the Hicksian form $Y_{t}=$ $\mathrm{A}_{\mathrm{t}} \mathrm{F}\left(\mathrm{K}_{\mathrm{t}}, \mathrm{L}_{\mathrm{t}}\right)$ underlying the Solow residual. ${ }^{9}$ In the labor-augmenting case, the goal is to measure the shift parameter $\mathrm{a}_{\mathrm{t}}$, which determines the evolution of technical efficiency.

However, it is important to recognize that technical change need not be Harrod neutral labor-augmenting technical change is a highly restrictive assumption in light of the IT revolution

\footnotetext{
9 An identification problem arises when the technology has the Cobb-Douglas form. In this case, $\mathrm{Y}_{\mathrm{t}}=\mathrm{K}_{\mathrm{t}}^{\alpha}\left(\mathrm{a}_{\mathrm{t}} \mathrm{L}_{\mathrm{t}}^{\beta}\right)$, which can be written as $Y_{t}=a_{t}^{\beta} K_{t}^{\alpha} L_{t}^{\beta}$. This is equivalent in measurement terms to the Hicks-neutral form $Y_{t}=A_{t}$ $\mathrm{K}_{\mathrm{t}}^{\alpha} \mathrm{L}_{\mathrm{t}}^{\beta}$. The identification problem is compounded when all countries are assumed to have a common $\beta$, the typical case in international growth comparisons.
} 
- and that, in any event, it is important to distinguish between the definition of technical change and the parametric specification of technical change. The standard definition is given in terms of the partial derivative of the production function with respect to time, holding inputs constant. Under the Harrodian definition, the time derivative is assessed holding $\mathrm{K} / \mathrm{Y}$ constant. Both definitions can be applied to the same function, and this function need not exhibit either Hicksian or Harrodian neutrality. For example, if the actual equilibrium point $\mathrm{y}_{00}$ were to lie somewhere to the right of $\underline{\mathrm{c}}$ in Figure 1, the shift in the function would still be measured along the line $\mathrm{P}$ from a to $\underline{\mathrm{c}}$, regardless of the underlying technology. Under the Harrodian definition, the increase in $\mathrm{y}_{00}$ beyond $\underline{\mathrm{c}}$ would be attributed to autonomous capital formation, even though technical change is Harrod-biased.

In practical terms, the residual estimate of TFP generated by the latter can be converted to the Harrodian residual by diving by labor's shares of income. ${ }^{10}$ The Hicksian and Harrodian definitions therefore give very different results, leading to the question of which convention is the 'right' one to use. The answer is that both are right, but for different questions. In order to find out how efficiently existing labor and capital are used, the Hicksian approach is the right way to proceed. However, if the question is about the relative importance of capital deepening versus efficiency change as the cause of growth, the Harrodian model gives the better answer, since capital formation is endogenous. Both are important and are complements rather than substitutes, but it is also important not to lose sight of which question is being answered. Thus, for example, in international comparisons of the technology gap that use the Harrodian

\footnotetext{
10 Hulten (1979) proposes a way to capture the induced accumulation effect without imposing either Hicksian of Harrodian forms of technical change, by treating capital as an intertemporal intermediate good. The resulting estimate of productivity change is shown to be the weighted sum of the Hicks-based residual, and to reduce to the Harrod-based residual when technical change happens to be Harrod neutral. Empirical work based on this framework reveals a substantial induced accumulation effect across countries (Hulten and Nishimizu, 1978).
} 
convention, e.g., Klenow and Rodriquez-Care (1997) and Hall and Jones (1999), the estimated gap should not be interpreted as a measure of the distance from the best-practice technologies of the rich countries, since the size of it depends on the rate of saving.

\section{E. Endogenous Growth}

Capital is not the only growth factor that is endogenous. Much of technical innovation is the result of systematic investments in education and research, and is thus part of overall (endogenous) capital formation. Moreover, in the framework developed in Lucas (1988) and Romer (1986), investments in education and research generate spillover externalities. These externalities may be sufficiently large that growth becomes endogenously self-sustaining, yielding the "AK" version of the model. ${ }^{11}$

All the growth rate of output is due to capital formation in the pure AK model. Thus, it would appear that the sources-of growth analysis of this case would generate sources-of growth estimates that attribute all of output per worker to capital, both in the rate of change and the level (that is, the TFP column would contain nothing but zeroes). However, this presumes that the extent of the externality is known. When it is not, and this is the normal case when growthaccounting data are derived from observed market transactions, it is not hard to show that the Solow residual measures the externality component of capital's contribution. ${ }^{12}$ The TFP residual now registers the externality effect, and TFP is reinterpreted accordingly. By implication,

\footnotetext{
${ }^{11}$ This can be illustrated by the Cobb-Douglas production on the preceding sections. That function can be expressed as $\mathrm{y}_{\mathrm{t}}=\mathrm{A}_{\mathrm{t}} \mathrm{k}_{\mathrm{t}}^{\alpha}$, where $\alpha$ and $\beta$ are the capital and labor output elasticities. In the standard neoclassical case of constant returns to scale, $\alpha+\beta=1$. In the endogenous growth case, the capital variable also throws off an externality, $\gamma$, so that $\mathrm{y}_{\mathrm{t}}=\mathrm{A}_{0} \mathrm{k}_{\mathrm{t}}^{\gamma} \mathrm{k}_{\mathrm{t}}^{\alpha}$. With $\alpha+\gamma=1$, the production function becomes $\mathrm{y}_{\mathrm{t}}=\mathrm{A}_{0} \mathrm{k}_{\mathrm{t}}$, a simple version of the "AK" model.

${ }^{12}$ In the endogenous growth case, $\mathrm{y}_{\mathrm{t}}=\mathrm{A}_{0} \mathrm{k}_{\mathrm{t}}^{\gamma} \mathrm{k}_{\mathrm{t}}^{\alpha}$. The Solow residual is based on the formulation $\mathrm{y}_{\mathrm{t}}=\mathrm{A}_{\mathrm{t}} \mathrm{k}_{\mathrm{t}}^{\alpha}$, implying that the TFP level index is $A_{t}=A_{0} k_{t}^{\gamma}$. In other words, TFP growth is entirely a function of capital formation in a pure endogenous growth situation. Conceptually, the apparent shift in the neoclassical production function is the result of the spillover externality. Endogenous growth theory can therefore be regarded as supplying one rationale for the shift in the production function, a shift that has been termed 'a measure of our ignorance' by Abramovitz (1956).
} 
differences in the growth rates and levels of TFP across countries are explained by externalities and driven by capital formation.

\section{F. Steady-State Growth Models}

The decompositions discussed thus far provide a backward-looking diagnosis of economic growth performance and its causes. Past performance is certainly a guide to the economic future, but it is not sufficient for forecasting the path ahead. It may be the case that a current income gap exists between two countries, but if they are converging to the same steadystate level of output per worker, their long-run economic futures will be the same. On the other hand, if one country is on a higher level of technology than another, both now and in the future, it will continue to be an income gap despite the convergence of $k_{t}$ to its steady-state path.

To study where countries are heading in the future requires a model that specifies more that just the production function, since the evolution of capital, labor, and technology must also be specified. The most fully developed empirical model that fits these requirements is the Mankiw, Romer, and Weil (1992) - henceforth MRW - model of neoclassical steady-state growth. MRW start with an augmented version of the Solow (1956) steady-state growth model and assume that all countries have the same Cobb-Douglas production function. They then solve the Solow model for its reduced form, which makes steady-state output per worker, $y^{*}$, a function of the following variables and parameters: the rate of saving in each country, $\sigma_{\mathrm{i}}$, the rate of growth in the labor force, $\eta_{\mathrm{i}}$, the depreciation of capital, $\delta$, and the Harrodian rate of technical change, $\lambda$. MRW then observe that actual output per worker, $\mathrm{y}_{\mathrm{t}}$, converges to the steady-state value according to an error-correction process that involves the rate of convergence. They proceed to use their reduced form equation to estimate the Cobb-Douglas output elasticities, $\alpha$ and $\beta$, and the rate of convergence to steady state. 
This approach is useful for the current purpose of decomposing steady-state output per worker into its long-run technology and capital formation components. The left-hand variable, $y^{*}$, can be estimated for each country given estimates of $\sigma_{i}, \eta_{i}, \delta, \lambda$, as well as estimates of the elasticities $\alpha$ and $\beta$ using income shares. The estimated $y^{*}$ is the level of output per worker toward which the actual level at any point in time, $\mathrm{y}_{\mathrm{t}}$, is converging. Like $\mathrm{y}_{\mathrm{t}}$, the estimated $\mathrm{y}^{*}$ must necessarily satisfy the production constraint, $\mathrm{y}^{*}=\mathrm{A}_{0}\left(\mathrm{k}^{*}\right)^{\alpha}$, where $\mathrm{k}^{*}$ is the steady-state value of capital per worker. This provides a natural decomposition of $y^{*}$ into the two components of interest, but one that is inherently forward looking. Moreover, the steady-state income gaps for any two countries, or groups of countries, can be compared and the size of the gap similarly decomposed into the two effects. We carry out both types of level comparison in the empirical section which follows, along with a decomposition of the growth rate of $y^{*}$ into its steady-state TFP and capital components.

\section{Data and Empirics}

The various theoretical approaches reviewed in the preceding section present a rich set of options for empirical work. They also present a challenge, because they offer different views and competing estimates of the same underlying growth process. We will explore, in this section, just how much the competing estimates differ. We start with the neoclassical sourcesof-growth model and the Hicksian convention for measuring TFP. This is by far the most common approach in the empirical growth literature and the one with the largest body of results.

\section{A. The Data Sources and Data Problems}

The sources-of-growth framework requires times series data on real output, labor input, capital stocks, and labor's share of income. These data are constructed for a total of 112 countries over the period 1970-2000. The list of countries, along with selected statistics, is 
shown in Table A.1 of the Data Appendix. In order to facilitate comparison, these countries are grouped into six 'meta' countries, mainly based on the World Bank classification by income per capita (not output per worker, which is highly correlated but not identical). The 40 Low Income countries are located in Africa, with eight exceptions. The 22 Lower-Middle Income countries are developing economies spread throughout the world, as are the 17 Upper-Middle Income countries. The 24 High-Income countries are basically those of the OECD. In addition, we have constructed two small meta-countries: four "Old Tigers" (Hong Kong, South Korea, Singapore, and Taiwan), and five "New Tigers" (China, India, Indonesia, Malaysia, and Thailand).

Our principal data source is the Penn World Tables 6.1 (Heston, Summers and Aten, 2002), from which real GDP (chain weighted) and real investment are obtained (both in power purchasing parity 1996 US dollars), as well as our labor force estimates. Real investment is used to compute the capital stock in international prices (details of this computation are given in the Appendix). ${ }^{13,14}$

The PWT data yield the estimates of $\mathrm{y}_{\mathrm{t}}$ and $\mathrm{k}_{\mathrm{t}}$ required by the sources-of-growth model. The final piece of data used in the paper, the country labor income shares, $\beta$, can be obtained from the United Nations Statistical Yearbook (various issues) and is simply computed as

\footnotetext{
${ }^{13}$ In the few cases where there were missing end years to the data series we have used the growth rate of real GDP in US\$, published in the World Bank's World Development Indicators 2004, and extrapolated our data based on these. For a more thorough discussion of the data and adjustments made to the data on labor force, we refer the reader to Isaksson (2007).

${ }^{14}$ Bosworth and Collins (2003) argue that capital goods valued in national prices are a better reflection of the capital costs faced by each country. They show that PPP-based capital stocks estimates have higher growth rates than the corresponding estimates using national prices, and that the former thus lead to an understatement of the TFP performance of poor countries. As a result, we constructed estimates based on national prices obtained from World Development Indicators (World Bank, 2004), for the 83 (out of 112) countries that had data for this comparison. The results for these two versions of capital are shown in Table A2 of the Appendix, for our six meta countries. While Table A2 generally supports the findings of Bosworth and Collins, the differences are not large enough to alter the results based on the more widely accepted PPP approach. The main difference arises in the Low Income meta country, where TFP growth does come to dominate. However, all of the growth rates for this case are quite close to zero. We have therefore opted to use the conventional PPP approach in this paper, but note that this is yet another area where data issues are importance, and where more work needs to be done.
} 
Compensation to Employees in GDP. As noted in the introduction, these estimates of are suspiciously low, ranging from 0.30 for the Low Income countries to 0.55 in the High Income (see Figure A.2). As noted in the introduction, this situation undoubtedly reflects an undercount of the income accruing to labor, especially in Low Income countries where there are many selfemployed and family workers, and many undocumented workers in the non-market economy. This has led a number of researchers to work with an externally imposed estimate of the factor shares, and a labor share of two-thirds and capital share of one-third is the typically employed. There is evidence to support this assumption, but also evidence against it. In a recent paper, Rodriguez and Ortega (2006) find that capital's income share in manufacturing industry declines by 6.25 percentage points for each log-point increase in GDP per capita. ${ }^{15}$ We will not attempt to sort out this issue, but instead present three sets of sources-of-growth estimates, one set calculated with a two-thirds labor share, another based on the average measured share, and a third using the Rodriguez-Ortega rule.

\section{B. Sources-of-Growth Estimates}

These estimates of the conventional Solow residual are shown in Tables 1a, 1b, and1c, respectively. The first column of Table 1a, which uses the two thirds/one third share rule as the basis for comparison, indicates that output per worker grew strongly over the period 1970 to 2000 in the High Income countries, but was close to zero in the Low Income group. The Lower Middle and Upper Middle Income meta countries display a positive growth experience, but still lag the growth rate of High Income leader. The Old and New Tigers, on the other hand, outperformed the leader in terms of growth. However, it is also the case that they started from a lower level of output per worker.

\footnotetext{
${ }^{15}$ By contrast, Duffy and Papageorgiou (2000) find that the elasticity of substitution - and hence the labor share falls with income.
} 
The second and third columns of Table 1a show the sources-of-growth decomposition of the growth rate of output per worker into its capital-deepening and TFP components. It is apparent that capital deepening is the predominant source of growth in the Low, Lower Middle, and Upper Middle Income countries, and that it accounts for about half of the growth in output per worker in the High Income. The Tiger countries are the exception to this pattern with TFP as the main source of growth, but not by a very large margin. These estimate speak directly to the question posed in Figure 1 about the relative magnitudes of the growth rates associated with the effects ( $\underline{a}$ to $\underline{b}$ ) and ( $\underline{b}$ to $\underline{c})$ : capital deepening, not TFP, is the dominant effect in the poorer lowgrowth countries, but this changes as the growth rate of output per worker rises. These results also speak to the debate whether capital deepening or productivity change is the main driver of growth (the 'perspiration versus inspiration' issue, as Krugman (1994) puts it). The estimates of Table 1a suggest that both perspiration and inspiration have important roles in a successful program of economic development. The finding that TFP grew rapidly in the (Old) Tigers stands in stark contrast to Young $(1992,1995)$, who argued that the contribution of TFP was only a negligible part of the East Asian miracle.

However, there is an important caveat. A comparison of the Low Income and High Income cases indicates that nearly sixty percent of the cross-sectional difference in the growth rate of $y_{t}$ between the high income meta country and the others is due to difference in TFP growth rates. In other words, capital deepening is the dominant source of growth over time in all but the most rapidly growing countries, but TFP is a more important factor in explaining crosssectional differences in growth performance. These results are very consistent with the estimates of Bosworth and Collins (2003), who use a similar set of assumptions and methods. 
The results shown in Table $1 \mathrm{~b}$ replay Table 1a using the average measured share of labor income, $\beta$, as estimated from the data (see Table 6). Since the share in the sources-of-growth model is a surrogate for the associated output elasticity, the shift to the measured $\beta$ greatly decreases the output elasticity of labor and increases that of capital, thereby giving greater weight to the growth rate of $\mathrm{k}_{\mathrm{t}}$ and strengthening the capital-deepening effect. In the case of Low Income countries, for example, the increase in the capital elasticity is from 0.33 to 0.71 , and the effect of this change is evident in the second and third columns of Table $1 \mathrm{~b}$. Capital deepening is now the overwhelmingly dominant source of growth over time in all the meta countries, although TFP is a still an important factor in explaining cross-sectional differences in growth performance, with the exception of the most rapidly growing countries.

The estimates of Table 1c offer a view of the sources of growth that is intermediate between the fixed 1/3-2/3 shares of Table 1a and the average measured labor shares of Table $1 \mathrm{~b}$. The shares in this case are based on the Rodriguez and Ortega (2006) finding that capital's income share in manufacturing industry declines by 6.25 percentage points for each log-point increase in GDP per capita. We apply this factor to the base value of capital's share in the High Income meta country, which we take to be 0.67 . Because the Rodriguez-Ortega adjustment generally increases capital's weight, capital deepening is now the leading source of growth in every meta country. However, estimates are much closer to those of Table 1a than $1 \mathrm{~b}$, and a major change occurs only in the New Tiger countries.

These three tables are based on estimates of capital stock derived using PPP price deflators. The Bosworth-Collins warning about the sensitivity of the results to the choice of price deflator bears repeating here. The use of national price deflators does give a somewhat 
different view of the problem, and this should be borne in mind when interpreting the results.

This is one more data issue to which more attention needs to be paid.

\section{The Sources of Development Estimates}

Tables $1 \mathrm{a}, 1 \mathrm{~b}$, and $1 \mathrm{c}$ approach the analysis of growth by examining the rate of growth of $\mathrm{y}_{\mathrm{t}}$ and the fraction explained by capital deepening and TFP. The sources-of-development analysis examines the parallel issue about the corresponding levels: what fraction of the level of $\mathrm{y}_{\mathrm{t}}$ is explained by the level of the capital-deepening effect and the TFP effects, that is, what is the actual magnitude of the distances ( $\underline{a}$ to $\underline{b}$ ) and ( $\underline{b}$ to $\underline{c}$ ) in Figure 1, and how much of the overall gap ( $\underline{a}$ to $\underline{\mathrm{c}})$ do they explain?

Recall, here, the example in which economies A and B grow by capital deepening alone, but one starts at a higher level of TFP. In that example, the entire growth rate in output per worker is due to capital deepening, but all the difference in the level of output per worker is due to the different level of productive efficiency. Table 2, which is based on the conventional income shares, $1 / 3-2 / 3$, suggests that a weaker form of this phenomenon occurs for many of the countries in our sample. The first column of this table reports the level of output per worker in the first five meta countries relative to the level of the High Income countries. This column conveys the same sense of the gap between rich and poor countries seen in Figure 2, which plots the paths of $y_{t}$ over time for the four largest groups of countries and the Tigers. The second column of Table 2 shows the relative levels of TFP, based on Caves, Christensen, and Diewert (1982a). It is clear from this table that the level of TFP in the first five meta countries is significantly below that of the High Income countries, and, while similar in pattern, are somewhat more compressed than the relative levels of output per worker. The latter is 16 times greater in the High Income countries compared to the Low, while the gap in productive 
efficiency is 'only' a factor of 5 . Figure 2 displays the time series trends that correspond to column 2. It reveals the same general magnitude as the relative TFP estimates of Table 2, and also indicates that the gap has widened over time for the Low, Lower Middle, and Upper Middle countries, but that the Tiger countries (Old and New) are narrowing the gap in the relative TFP level.

The last three columns of Table 2 decompose the level of output per worker into its capital-deepening and TFP components. This decomposition is based on the assumption that the production function has the simple constant-returns Cobb-Douglas form $\mathrm{y}_{\mathrm{t}}=\mathrm{A}_{\mathrm{t}} \mathrm{k}_{\mathrm{t}}^{(1-\beta)}$ (again, this is implicit in the assumption of a constant value of the labor share, $\beta$ ). The variable $A_{t}$ is the basis for TFP in the Solow model, and the level of TFP can thus be estimated by computing the ratio $\mathrm{y}_{\mathrm{t}} / \mathrm{k}_{\mathrm{t}}^{(1-\beta)}$. This 'CD' index is not necessarily equivalent to the CCD index, but when the $\beta$ shares have the same value for each country, and the Cobb-Douglas index is normalized to the High Income countries, it gives the same values as the CCD index (thus, the numbers in columns 2 and 3 are identical).

To assess the relative importance of capital deepening and TFP on the level of (unnormalized) output per worker, the logarithm $y_{t}$ is divided between the logarithms of $A_{t}$ and $\mathrm{k}_{\mathrm{t}}^{(1-\beta)}$. This decomposition is shown in the last three columns of Table 2, where it is apparent that the TFP is the predominant factor explaining the level of output per worker. Moreover, a little more than half of the cross-sectional variation among countries is explained by the difference in the level of TFP. This is the disconnect between the growth-rate analysis of Table 1a and the level analysis of Table 2 noted above. For example, TFP growth explains none of the growth rate in output per worker in the Low Income meta country, but the corresponding TFP level explains $66 \%$ of the level of output per worker. For the Lower and Upper Middle meta 
countries, these numbers are $40 \%$ and $65 \%$, and for the High Income case, they are $49 \%$ and $64 \%$. This disconnect is diminished, but not absent, in the high growth Tiger meta countries.

In other words, Table 1a suggests that their growth is propelled more by capital deepening rather than TFP growth, but Table 2 indicates that the main factor in explaining the large gap in output per worker is the persistently low levels of TFP in these countries (compare, also, Figures 2 and 3). Not all of the 67 countries in the Low, Lower Middle, and Upper Middle income meta groups are subject to this pattern. And, significantly, the Tiger countries display a convergence toward the High Income case, in both output per worker and in TFP levels, powered in part by a rapid rate of TFP growth. This pattern suggests that, in the large, successful development programs are powered by an acceleration in TFP growth relative to that of the High Income leaders, and that the gap in TFP levels in thereby narrowed. An acceleration in capital per worker is also an important (albeit lesser) factor. Whether the former drives the latter, as in the Harrodian view, or vice versa, as in the endogenous growth view, cannot be learned from sources-of-growth estimates, but whatever the dynamics associated with TFP growth and levels, the estimates of Tables 1a and 2 assign a centrally important role to measured TFP.

D. Empirical Results from the Harrodian and Endogenous Technology Approaches

The Harrodian version of the growth decomposition is shown in the last two columns of Tables 1a-1c. In practical terms, Harrodian TFP in column 5 is computed by dividing the corresponding Hicksian estimate in column 3 by labor's income share. This procedure results in a larger effect attributed to productivity, since part of the growth $\mathrm{k}_{\mathrm{t}}$ (the induced accumulation) is reassigned to TFP. This result carries over from growth rates to levels, which are not shown, since in the common-share Cobb-Douglas case, the Harrodian levels are a simple power transformation (based on $\beta$ ) of the Hicksian level estimates of Table 2. 
Endogenous growth theory implies a very different sources-of-growth decomposition. Where the Harrodian approach reallocates the induced-accumulation part of capital formation to TFP growth, the endogenous growth view reallocates the capital-induced part of TFP growth to capital formation. In the most extreme form, all of TFP growth is endogenous. If additional (endogenous growth) columns were added to Tables $1 \mathrm{a}, 1 \mathrm{~b}$, and $1 \mathrm{c}$, with the capital-deepening effect shown in a sixth column and the TFP effect in a seventh, the new column 6 would equal the entire growth rate of output per worker, and the column 7 would contain nothing but zeroes. Since this decomposition is essentially trivial, from an expositional standpoint, it is not included in the various tables.

\section{The Predictions of Growth Theory}

The insights offered in the preceding sections about the growth process and the income gap are inherently retrospective. They are based on the experience of past decades, but do not answer to the following question: if past trends persist into the future, will they be enough to lift a poor nation out of poverty? Are the trends in TFP and capital formation such that the poorest countries will ultimately converge to the levels achieved by the rich and thereby extinguish the income gap? These questions are inherently about future outcomes, and the answers require a fully-specified model of growth that takes into account the full range of factors that determine the future growth path.

\section{A. Decompositions Based on Growth Models}

We have already encountered the two main contenders for this role: the endogenous growth model and the neoclassical model of steady-state growth. The growth dynamics of the former stress the role the capital formation and, in its $\mathrm{AK}$ form, predicts that those countries that are able to build an initial lead in capital per worker will be able to exploit the advantage and pull 
away from the others. This prediction accords well with the pattern seen in Figure 2, and implies a fairly bleak outlook for the growth of the lower income countries. However, it does not fit well with the experience of 'transition' economies like the Tigers that are able to accelerate growth by a combination of increased capital formation and more importantly, according to Table 1a, by even stronger TFP growth.

The neoclassical model, as interpreted by MRW (1992), does allow for some countries to catch up to the leaders while others stagnate. MRW solve for the reduced form of the Solow steady-state model when the technology of every country has the same Cobb-Douglas form and output elasticities. They use the equation for steady-state output per worker, adjusted to allow convergence to steady-state, to estimate the elasticities. In this paper, we take this equation to estimate steady-state output per worker for each meta country, $\mathrm{y}^{*}$, by using the 'two-thirds/onethird' rule for the income share as an estimate of the Cobb-Douglas elasticities, and by estimating the other variables in the reduced form: the investment rate, $\sigma$, the rate labor force growth, $\eta$, the rate of depreciation, $\delta$, the Harrodian rate of technical change, $\lambda$, and the level of TFP in the comparison year $2000, \mathrm{~A}_{2000}$.

The MRW model assumes the Cobb-Douglas form with constant returns to scale, so that $y_{t}^{*}=A_{t} k_{t}^{*(1-\beta)}$. The steady-state solution for $y^{*}$ in each of the six meta countries is shown in the first column of Table 3 for the last year in our sample, 2000. The actual level of output per worker in 2000 is shown for comparison in the adjacent column. The salient result is that there is a huge gap in output per worker between the Low and High Income countries (a ratio of 17 to 1 in 2000), and this gap is set to persist into the indefinite future. Moreover, this is true even if the Low Income meta country's rate of productivity growth $\lambda$ were to improve to the rate prevailing in the High Income case. In fact, the Low Income country would have to improve the growth rate 
of TFP to that of the High Income country just to maintain the year 2000 gap. If the $\lambda$ 's shown in last column of Table 1a persist into the future, the gap will widen. Similar remarks apply, to a lesser extent, for the Lower Middle and Upper Middle Income meta countries. The steady-state picture is only bright for the Old Tiger countries, whose $\mathrm{y}^{*} 2000$ is around one- half of the High Income amount, and whose $\lambda$ is larger.

The sources of the gap are examined in Table 4, which decomposes the gap between steady-state output per worker in the rich and poor countries into the separate contributions of capital-deepening and TFP. This analysis is parallel to the sources-of-development level decomposition shown in Table 2, but the novelty here is that the decomposition refers to the long-run equilibrium contributions of the two sources when capital formation is endogenous (relative to a given rate of saving).

The sources of the income gap are further examined in Table 4. The difference in the level of steady-state output per worker is in the High Income meta country $(\mathrm{H})$ compared to the Low Income (L) country is $\left(\mathrm{y}^{*} \mathrm{H}-\mathrm{y}^{*} \mathrm{~L}\right)$, which can be decomposed into two effects. The first is the gap $\left(\mathrm{y}_{\mathrm{L}} \mathrm{-}-\mathrm{y}_{\mathrm{f}}\right)$, the distance between the L's steady-state, $\mathrm{y}_{\mathrm{L}}^{*}$, and the point on its own production function that economy $\mathrm{L}$ would attain if it operated with the saving and population growth parameters rather than its own parameters, $\mathrm{y}_{\mathrm{f}}$. The second component of the decomposition is the distance between the two production functions, $\left(\mathrm{y}_{\mathrm{f}}-\mathrm{y}_{\mathrm{L}} \mathrm{L}\right)$, as measured in the Harrodian way along the high income growth path. This decomposes the steady-state output per worker gap into capital-deepening and efficiency effects based on the saving and population growth parameters of the high income country.

A look at column 1 of Table 4 shows the dollar magnitude of the total gap $\left(\mathrm{y}^{*}{ }_{\mathrm{H}}-\mathrm{y}^{*} \mathrm{~L}\right)$ for each of the meta countries in the year 2000, while the next columns gives capital-deepening, the 
difference $\left(\mathrm{y}_{\mathrm{f}}-\mathrm{y}_{\mathrm{L}} \mathrm{L}\right)$, and technology effects, $\left(\mathrm{y}^{*} \mathrm{H}_{\mathrm{f}}-\mathrm{y}_{\mathrm{f}}\right)$. Several conclusions emerge from these estimates. First, the large gap between the High Income countries and the others evident in Figure 2 appears to be a long-run situation as long as the basic parameters of growth remain unchanged (the exception here, as before, is the Tiger countries). Second, the gap in output per worker is largely explained by the technology gap, not differences in the propensity to accumulate capital relative to the growing labor force (this is also apparent in the first two columns of Table 5, which express the Table 4 decomposition in percentage terms). Finally, the forward-looking role played by TFP is even stronger than the role suggested by Figure 3 .

However, this result must be qualified by the fact that the decomposition is not unique. We could equally decompose the steady-state output per worker gap into capital-deepening and efficiency effects based on the saving and population growth parameters of the low income country. The third and fourth columns of Table 5 show the splits for these alternative paths (the “Actual Income Path" for each country). The alternative results are quite different, suggesting a high degree of path dependence, and to arrive at a single index, the average values for the two cases are shown in the last two columns of the table. The results support the overall conclusion that the TFP effect is still the most important source for explaining the gap $\left(\mathrm{y}^{*} \mathrm{H}-\mathrm{y}^{*} \mathrm{~L}\right)$, as well as the conclusion that the gap looks set to persist into the future.

\section{B. Steady-State Sources-of-Growth Estimates}

Tables 4 and 5 decompose the steady-state levels of output per worker into its long-run capital and Harrodian TFP components. For the sake of completeness, we now return to Table 1a and add the sources-of-growth rates decomposition implied by the steady-state framework. The steady-state analogue to Table 1a can be calculated from the basic parameters and estimates of the steady-state growth, since, along the steady-state path, output per worker, $\mathrm{y}^{*}$, and capital 
per worker, $\mathrm{k}^{*}$, grow at the same rate $\lambda$. In other words, Harrodian productivity is the sole driver of the steady-state growth in output per worker in the neoclassical model. Thus, the first column of a steady-state analogue to Table 1a would record the $\lambda$ appropriate for each country, and Harrodian decomposition in the fourth and fifth columns would have the values 0 (for the capital-deepening effect) and $\lambda$ (for the TFP effect), since all capital formation is induced accumulation and is assigned to TFP. This represents the true picture of growth, conditional on accepting the validity of the experiment with the neoclassical model.

In the steady-state version of the standard sources-of-growth model developed by Solow, the growth rate of output per worker is $y^{*}$ and the capital-deepening effect is $(1-\beta) \mathrm{k}^{*}$, and the TFP effect is the residual $\mathrm{y}^{*}-(1-\beta) \mathrm{k}^{*}$. This implies that the Hicksian decomposition would record (1- $\beta) \lambda$ for the capital effect and $\beta \lambda$ for the TFP contribution. These are not the correct numbers with which to assess the relative contribution of each effect, and this establishes the fact the Solow residual growth model, so widely used in empirical growth theory, is asymptotically biased. Again, this bias is the counterpart of the simultaneous equations bias arising is econometrics from the endogeneity of capital.

\section{Conclusion}

Our analysis points to the persistently low levels of technological efficiency as the proximate source of the gap between the rich and poorer countries. In this, we confirm many other studies of this issue. We have not attempted to explain the causes of the technology gap, be they due to institutional and environmental factors, the externalities associated with capital formation, or whatever. We have chosen, instead, to examine the prior issue of how to measure the gap, and have compared different techniques and assumptions using a common set of data. This examination has led us to the following conclusions. 
First, the conventional analysis of differential growth rates needs to be supplemented by a parallel analysis of growth levels. Capital deepening explains more than half of the growth rate of output per worker in a majority of countries, while TFP explains more than half of the corresponding gap. Only in the rapid-growth Tiger countries does TFP growth outweigh capital formation, and then only by a small margin.

Second, the Hicks and Harrod ways of measuring the relative levels of the technology gap are both relevant, but they are relevant for answering different questions. The former measures the extra output that could be obtained from the current quantities of capital and labor by moving to a higher level of TFP, while the latter includes the additional output arising from the savings generated by the gain in productive efficiency. The latter is larger and is relevant from understanding the overall impact of TFP, but if the goal is to understand the causes of a low level of productive efficiency, per se, the Hicksian approach seems better suited to the task.

Third, in the endogenous growth approach, the induced-technology effect appears as a shift in the production function in the conventional Hicks-Solow measurement framework, so a positive gap in measured TFP is not inconsistent with the endogenous growth model. Indeed, endogenous growth effects are among the factors than can be adduced to explain the gap.

Fourth, the measurement procedures used in the literature to measure the income and technology gaps are inherently backward looking. A large income gap between rich and poor countries is less of a concern if the growth paths of the two will converge in the future. This can only be learned from a modeling exercise that endogenizes the growth path, rather than taking the sources of growth as being exogenously determined as in the Solow residual model. We use the neoclassical model for this purpose, and develop a steady-state decomposition of output per worker into capital deepening and Harrodian-TFP components. We find that this forward- 
looking model predicts that the large gap will not close in the future for most of the developing countries unless they are able to significantly improve both the growth rates of the capital per worker and TFP. This conclusion must be tempered by the highly abstract nature of the neoclassical growth model, but the size of the predicted long-run gaps are suggestive of the potential magnitude of future income gaps. The steady-state analysis is also useful in pointing out the existence of an asymptotic bias in the conventional Solow approach to the sources of growth.

Finally, it is important to emphasize, once again, that there are significant gaps in the data. The problem is most apparent in the implausibly low labor shares implied by national accounting data for lower income countries, and the resulting practice of imposing a common two-thirds share on all countries. The output elasticities of capital and labor, as proxied by the share, are a key determinant of output growth, and the consequences of using different measures of the labor share are evident in the estimates of Tables $1 \mathrm{a}, 1 \mathrm{~b}$, and $1 \mathrm{c}$ of this paper. It is intellectually disturbing that our understanding of the growth process should rest on such shaky data foundations. And, data issues are by no means limited to the problem with measured income shares. The accuracy of capital measures is also an issue, particularly with the Bosworth-Collins point about the large difference that arises when national prices are substitutes for PPP price. It would be well, in closing, to recall the words of Zvi Griliches, who observed:

"We [economists] ourselves do not put enough emphasis on the value of data and data collection in our training of graduate students and in the reward structure of our profession. It is the preparation skill of the chef that catches the professional eye, not the quality of the materials in the meal, or the effort that went into procuring them." (AER 1994) 


\section{References}

Abramovitz, Moses, "Resource and Output Trends in the United States since 1870," American Economic Review, 46, 2, May 1956, 5-23.

Bosworth, Barry P., and Susan M. Collins, "The Empirics of Growth: An Update," Brookings Papers on Economic Activity: 2, 2003, 113-206.

Caves, Douglas W., Laurits R. Christensen, and W. Erwin Diewert, "Multilateral Comparisons of Output, Input, and Productivity Using Superlative Index Numbers," Economic Journal, 92, March 1982a, 73-86.

Caves, Douglas W., Laurits R. Christensen, and W. Erwin Diewert, "The Economic Theory of Index Numbers and the Measurement of Input, Output, and Productivity," Econometrica, 50, 6, November 1982b, 1393-1414.

Christensen, Laurits R., Diane Cummings, and Dale W. Jorgenson, "Relative Productivity Levels, 1947-1973: An International Comparison," European Economic Review, 16, 1981, 61-94.

Denison, Edward F., Why Growth Rates Differ: Postwar Experiences in Nine Western Countries, The Brookings Institution, Washington, D.C., 1967.

Diewert, W. Erwin, "Exact and Superlative Index Numbers," Journal of Econometrics, 4, 1976, 115-145.

Dowrick Steven and Duc-Tho Nguyen, "OECD Comparative Economic Growth 1950-85: Catch-up and Convergence," American Economic Review, 79(5), December 1989, 10101030 .

Duffy, John and Chris Papageorgiou, "A Cross-Country Empirical Investigation of the Aggregate Production Function Specification," Journal of Economic Growth, 5(1), 87120, March 2000.

Fisher, Franklin, "Embodied Technical Change and the Existence of an Aggregate Capital Stock," Review of Economic Studies, 1965, 326-388.

Fisher, Franklin, "The Existence of Aggregate Production Functions.” The Irving Fisher Lecture at the Econometric Society Meetings, Amsterdam, September 1968; Econometrica, Vol. 37, No. 4, October 1969, pp. 553-577.

Färe, Rolf, Shawna Grosskopf, Mary Norris, and Zhongyang Zhang, "Productivity Growth, Technical Progress, and Efficiency Change in Industrialized Countries," American Economic Review, 84, 1, March 1994, 66-83. 
Gollin, Douglas, "Getting Income Shares Right," Journal of Political Economy, 110(2), 2002, 458-74.

Griliches , Zvi, "Productivity, R\&D, and the Data Constraint," American Economic Review, 84, 1, March 1994, 1-23.

Hall, Robert E. and Charles I. Jones, "Why Do Some Countries Produce So Much More Output Per Worker Than Others?” The Quarterly Journal of Economics 114(1), 1999, 83-116.

Heston, Alan, Robert Summers and Bettina Aten, Penn World Table Version 6.1, Center for International Comparisons at the University of Pennsylvania (CICUP), October 2002.

Hulten, Charles R., "Technical Change and the Reproducibility of Capital," American Economic Review, 65, 5, December 1975, 956-965.

Hulten, Charles R., "On the 'Importance' of Productivity Change," American Economic Review, $69,1979,126-136$.

Hulten, Charles R., "Total Factor Productivity: A Short Biography," in New Developments in Productivity Analysis, Charles R. Hulten, Edwin R. Dean, and Michael J. Harper, eds., Studies in Income and Wealth, vol. 63, The University of Chicago Press for the National Bureau of Economic Research, Chicago, 2001, pp. 1-47.

Isaksson, Anders, "World Productivity Database", mimeograph, Vienna: UNIDO. January 2007.

Jorgenson, Dale W. and Zvi Griliches, "The Explanation of Productivity Change," Review of Economic Studies, 34, July 1967, 349-83.

Jorgenson, Dale W. and Mieko Nishimizu, "U.S. and Japanese Economic Growth, 19521974. An International Comparison." Economic Journal, December, 1978, 707-726.

Klenow, Peter, and Andrés Rodriguez-Clare, "The Neoclassical Revival in Growth Economics: Has It Gone Too Far?” In National Bureau of Economic Research Macroeconomics Annual 1997, edited by Ben S. Bernanke and Julio Rotemberg. Cambridge, MA: MIT Press, 1997, 73-103.

Krugman, Paul, "The Myth of Asia's Miracle," Foreign Affairs, 73, 6, November/December, 1994, 62-77.

Landes, David S., The Wealth and Poverty of Nations: Why Some Countries are So Rich and Some So Poor, W.W. Norton \& Company, New York, 1998.

Lucas, Robert E. Jr., “On the Mechanics of Economic Development," Journal of Monetary Economics, 22, 1988, 3-42. 
Maddison, Angus, "Growth and Slowdown in Advanced Capitalist Economies: Techniques and Quantitative Assessment," Journal of Economic Literature, 25, 2, June 1987, 649-698.

Mankiw, N. Gregory, David Romer, and David N. Weil, "Contribution to the Empirics of Economic Growth, Harvard University," The Quarterly Journal of Economics, May $1992,407-437$.

Nishimizu, Mieko and Charles Hulten, “The Sources of Japanese Economic Growth, 1955-71," Review of Economics and Statistics, 60(3), 1978, 351-361.

Rodriguez, Francisco and Daniel Ortega, "Are Capital Shares Higher in Poor Countries? Evidence from Industrial Surveys," Wesleyan Economics Working Papers, No: 2006-023, 2006.

Romer, Paul M., "Increasing Returns and Long-Run Growth,” Journal of Political Economy, 94(5), 1986, 1002-1052.

Solow, Robert M., "A Contribution to the Theory of Economic Growth.” Quarterly Journal of Economics, 70, 1956, February, 65-94.

Solow, Robert M., "Technical Change and the Aggregate Production Function." Review of Economics and Statistics, 39, 1957, 312-320.

United Nations, National Accounts Statistics: Main Aggregates and Detailed Tables, Department of Economic and Social Affairs, Statistics Division, United Nations, New York, various years.

Young, Alwyn, "A Tale of Two Cities: Factor Accumulation and Technical Change in Hong Kong and Singapore, In Blanchard, O.J., and S. Fisher, eds., NBER Macroeconomics Annual 1992, Cambridge Mass: MIT Press, 1992, 13-54.

--------, "Tyranny of Numbers: Confronting the Statistical Realities of the East Asian Growth Experience," Quarterly Journal of Economics, August 1995, 641-680.

World Bank, World Development Indicators 2004, World Bank, Washington, DC, 2004. 
TABLE 1a

SOURCES OF GROWTH

COMMON SHARES

1970-2000

\begin{tabular}{lccccc}
\hline & \multicolumn{2}{c}{ CONVENTIONAL (HICKS) } & \multicolumn{2}{c}{ HARROD } \\
\hline \multicolumn{3}{c}{ META } & AAGR & AAGR & AAGR \\
COUNTRY & Y/L & TFP & $\begin{array}{c}\text { AAGR } \\
\text { K/L }\end{array}$ & $\begin{array}{c}\text { AAGR } \\
\text { TFP }\end{array}$ \\
& & & & & \\
\hline Low Income & $0.17 \%$ & $0.25 \%$ & $-0.07 \%$ & $0.28 \%$ & $-0.11 \%$ \\
Low-Middle & $1.01 \%$ & $0.61 \%$ & $0.40 \%$ & $0.41 \%$ & $0.60 \%$ \\
Upper-Middle & $0.99 \%$ & $0.59 \%$ & $0.40 \%$ & $0.39 \%$ & $0.60 \%$ \\
New Tigers & $3.79 \%$ & $1.70 \%$ & $2.09 \%$ & $0.68 \%$ & $3.12 \%$ \\
Old Tigers & $4.89 \%$ & $2.37 \%$ & $2.52 \%$ & $1.13 \%$ & $3.76 \%$ \\
High & $1.95 \%$ & $1.00 \%$ & $0.95 \%$ & $0.53 \%$ & $1.42 \%$ \\
\hline
\end{tabular}

AAGR $=$ Average Annual Growth Rate

TABLE $1 b$

SOURCES OF GROWTH

1970-2000

MEASURED SHARES

CONVENTIONAL (HICKS) HARROD

\begin{tabular}{lccccc}
\hline $\begin{array}{l}\text { META } \\
\text { COUNTRY }\end{array}$ & $\begin{array}{c}\text { AAGR } \\
\text { Y/L }\end{array}$ & $\begin{array}{c}\text { AAGR } \\
\text { K/L }\end{array}$ & $\begin{array}{c}\text { AAGR } \\
\text { TFP }\end{array}$ & $\begin{array}{c}\text { AAGR } \\
\text { K/L }\end{array}$ & $\begin{array}{c}\text { AAGR } \\
\text { TFP }\end{array}$ \\
\hline Low Income & $0.17 \%$ & $0.52 \%$ & $-0.35 \%$ & $1.37 \%$ & $-1.19 \%$ \\
Low-Middle & $1.01 \%$ & $1.17 \%$ & $-0.16 \%$ & $1.45 \%$ & $-0.44 \%$ \\
Upper-Middle & $0.99 \%$ & $1.05 \%$ & $-0.06 \%$ & $1.14 \%$ & $-0.15 \%$ \\
New Tigers & $3.79 \%$ & $3.53 \%$ & $0.26 \%$ & $2.97 \%$ & $0.83 \%$ \\
Old Tigers & $4.89 \%$ & $3.92 \%$ & $0.97 \%$ & $2.76 \%$ & $2.13 \%$ \\
High & $1.95 \%$ & $1.36 \%$ & $0.58 \%$ & $0.88 \%$ & $1.07 \%$ \\
& & & & & \\
\hline
\end{tabular}

AAGR $=$ Average Annual Growth Rate 
TABLE 1c

SOURCES OF GROWTH

1970-2000

RODRIGUEZ-ORTEGA SHARES

\begin{tabular}{lccccc}
\hline & \multicolumn{2}{c}{ CONVENTIONAL (HICKS) } & \multicolumn{2}{c}{ HARROD } \\
\hline META & AAGR & AAGR & AAGR \\
KOUNTRY & Y/L & AAGR & AAGR \\
& & & & & KFP \\
\hline & & & & & \\
Low Income & $0.17 \%$ & $0.38 \%$ & $-0.20 \%$ & $0.59 \%$ & $-0.41 \%$ \\
Low-Middle & $1.01 \%$ & $0.79 \%$ & $0.22 \%$ & $0.62 \%$ & $0.39 \%$ \\
Upper-Middle & $0.99 \%$ & $0.68 \%$ & $0.31 \%$ & $0.49 \%$ & $0.50 \%$ \\
New Tigers & $3.79 \%$ & $2.49 \%$ & $1.31 \%$ & $1.27 \%$ & $2.52 \%$ \\
Old Tigers & $4.89 \%$ & $2.67 \%$ & $2.23 \%$ & $1.36 \%$ & $3.54 \%$ \\
High & $1.95 \%$ & $1.00 \%$ & $0.95 \%$ & $0.53 \%$ & $1.42 \%$ \\
& & & & & \\
\hline
\end{tabular}

AAGR $=$ Average Annual Growth Rate

TABLE 2

LEVELS OF GROWTH AND PRODUCTIVITY

1970-2000

COMMON SHARES

\begin{tabular}{|c|c|c|c|c|c|c|}
\hline META & LEVEL & LEVEL & LEVEL & LOG & LOG & LOG \\
\hline COUNTRY & $\mathrm{Y} / \mathrm{L}$ & CCD-TFP & CD-TFP & $\mathrm{Y} / \mathrm{L}$ & $\mathrm{K} / \mathrm{L}$ & TFP \\
\hline Low Income & $6.05 \%$ & $19.84 \%$ & $19.84 \%$ & 7.76 & 2.61 & 5.15 \\
\hline Low-Middle & $22.46 \%$ & $43.41 \%$ & $43.41 \%$ & 9.08 & 3.14 & 5.93 \\
\hline Upper-Middle & $44.47 \%$ & $63.30 \%$ & $63.30 \%$ & 9.76 & 3.45 & 6.31 \\
\hline New Tigers & $8.50 \%$ & $23.57 \%$ & $23.57 \%$ & 8.09 & 2.78 & 5.31 \\
\hline Old Tigers & $49.53 \%$ & $67.24 \%$ & $67.24 \%$ & 9.83 & 3.48 & 6.35 \\
\hline High & $100.00 \%$ & $100.00 \%$ & $100.00 \%$ & 10.57 & 3.81 & 6.77 \\
\hline
\end{tabular}


TABLE 3

COMPARISON OF STEADY-STATE AND ACTUAL

LEVELS OF OUTPUT PER WORKER, 2000

COMMON SHARES

\begin{tabular}{lccc}
\hline META & $\begin{array}{c}\text { STEADY } \\
\text { STATE } \\
\text { COUNTRY }\end{array}$ & $\begin{array}{c}\text { ACTUAL } \\
\text { y }\end{array}$ & $\begin{array}{c}\text { REMAINING } \\
\text { GAP } \\
\left(\mathrm{y}^{*}-\mathrm{y}\right) / \mathrm{y} *\end{array}$ \\
\hline Low Income & $\$ 2,452$ & $\$ 2,340$ & $5 \%$ \\
Low-Middle & $\$ 9,924$ & $\$ 8,811$ & $11 \%$ \\
Upper-Middle & $\$ 18,617$ & $\$ 17,402$ & $7 \%$ \\
New Tigers & $\$ 7,059$ & $\$ 3,531$ & $51 \%$ \\
Old Tigers & $\$ 26,383$ & $\$ 20,905$ & $23 \%$ \\
High & $\$ 48,538$ & $\$ 39,954$ & $18 \%$ \\
\hline
\end{tabular}

TABLE 4

DECOMPOSITION OF STEADY-STATE OUTPUT GAPS

INTO CAPITAL-DEEPENING AND TFP COMPONENTS

ALONG HIGH-INCOME GROWTH PATH

COMMON SHARES, 2000

\begin{tabular}{lccc}
\hline $\begin{array}{c}\text { META } \\
\text { COUNTRY }\end{array}$ & $\begin{array}{c}\text { TOTAL } \\
\text { GAP } \\
\left(\mathrm{y}^{*} \mathrm{H}^{*}{ }_{\mathrm{i}}\right)\end{array}$ & $\begin{array}{c}\text { CAPITAL- } \\
\text { DEEPENING } \\
\text { GAP } \\
\left(\mathrm{y}^{*} \mathrm{H}^{*} \boldsymbol{y}_{\mathrm{if}}\right)\end{array}$ & $\begin{array}{c}\text { HARROD } \\
\text { TFP } \\
\text { GAP } \\
\left(\mathrm{y}^{*}{ }_{\text {if }}-\mathrm{y}_{\mathrm{i}}\right)\end{array}$ \\
\hline Low Income & $\$ 56,783$ & $\$ 1,743$ & $\$ 55,040$ \\
Low-Middle & $\$ 48,393$ & $\$ 4,570$ & $\$ 43,823$ \\
Upper-Middle & $\$ 38,926$ & $\$ 5,282$ & $\$ 33,644$ \\
New Tigers & $\$ 47,648$ & $\$ 10$ & $\$ 47,639$ \\
Old Tigers & $\$ 16,029$ & $\$ 36$ & $\$ 15,993$ \\
High & $\$ 0$ & $\$ 0$ & $\$ 0$ \\
\hline
\end{tabular}


TABLE 5

PERCENTAGE DECOMPOSITION OF STEADY-STATE INCOME GAPS

INTO CAPITAL-DEEPENING AND TFP COMPONENTS

WITH DIFFERENT GROWTH PATHS

COMMON SHARES, 2000

\begin{tabular}{|c|c|c|c|c|c|c|}
\hline \multirow{3}{*}{$\begin{array}{c}\text { META } \\
\text { COUNTRY }\end{array}$} & \multicolumn{2}{|c|}{$\begin{array}{c}\text { HIGH INCOME } \\
\text { PATH }\end{array}$} & \multicolumn{2}{|c|}{$\begin{array}{c}\text { ACTUAL INCOME } \\
\text { PATH }\end{array}$} & \multicolumn{2}{|c|}{$\begin{array}{c}\text { AVERAGE } \\
\text { PATH }\end{array}$} \\
\hline & $\%$ & $\%$ & $\%$ & $\%$ & $\%$ & $\%$ \\
\hline & CAPITAL & TFP & CAPITAL & TFP & CAPITAL & TFP \\
\hline Low Income & $3 \%$ & $97 \%$ & $44 \%$ & $56 \%$ & $23 \%$ & $77 \%$ \\
\hline Low-Middle & $9 \%$ & $91 \%$ & $36 \%$ & $64 \%$ & $23 \%$ & $77 \%$ \\
\hline Upper-Middle & $14 \%$ & $86 \%$ & $31 \%$ & $69 \%$ & $23 \%$ & $77 \%$ \\
\hline New Tigers & $0 \%$ & $100 \%$ & $0 \%$ & $100 \%$ & $0 \%$ & $100 \%$ \\
\hline Old Tigers & $0 \%$ & $100 \%$ & $0 \%$ & $100 \%$ & $0 \%$ & $100 \%$ \\
\hline
\end{tabular}

TABLE 6

COMPARISON OF STEADY-STATE PARAMETERS

AVERAGE VALUES 1970-2000

\begin{tabular}{lcccccc}
\multicolumn{1}{c}{$\begin{array}{c}\text { META } \\
\text { COUNTRY }\end{array}$} & $\beta_{\text {STD }}$ & $\begin{array}{c}\text { SHABR'S } \\
\beta_{\text {MEASURED }}\end{array}$ & $\beta_{\text {R-O }}$ & $\begin{array}{c}\text { SAVING } \\
\text { RATE } \\
\sigma\end{array}$ & $\begin{array}{c}\text { LABOR } \\
\text { GROWTH } \\
\eta\end{array}$ & $\begin{array}{c}\text { POPULATION } \\
\text { GROWTH }\end{array}$ \\
\hline Low Income & 0.667 & 0.294 & 0.493 & 0.093 & 0.024 & 0.026 \\
Low-Middle & 0.667 & 0.367 & 0.576 & 0.144 & 0.027 & 0.024 \\
Upper-Middle & 0.667 & 0.412 & 0.618 & 0.178 & 0.025 & 0.020 \\
New Tigers & 0.667 & 0.316 & 0.518 & 0.281 & 0.021 & 0.017 \\
Old Tigers & 0.667 & 0.455 & 0.630 & 0.281 & 0.024 & 0.013 \\
High & 0.667 & 0.548 & 0.667 & 0.231 & 0.011 & 0.007
\end{tabular}

$\beta_{\mathrm{STD}}=$ Standard approach; $\beta_{\mathrm{MEASURED}}=$ As reported; $\beta_{\mathrm{R}-\mathrm{O}}=$ As implied by Rodriguez-Ortega (2006) 
Figure 1. Output per Worker, Level of TFP and Capital-deepening effect

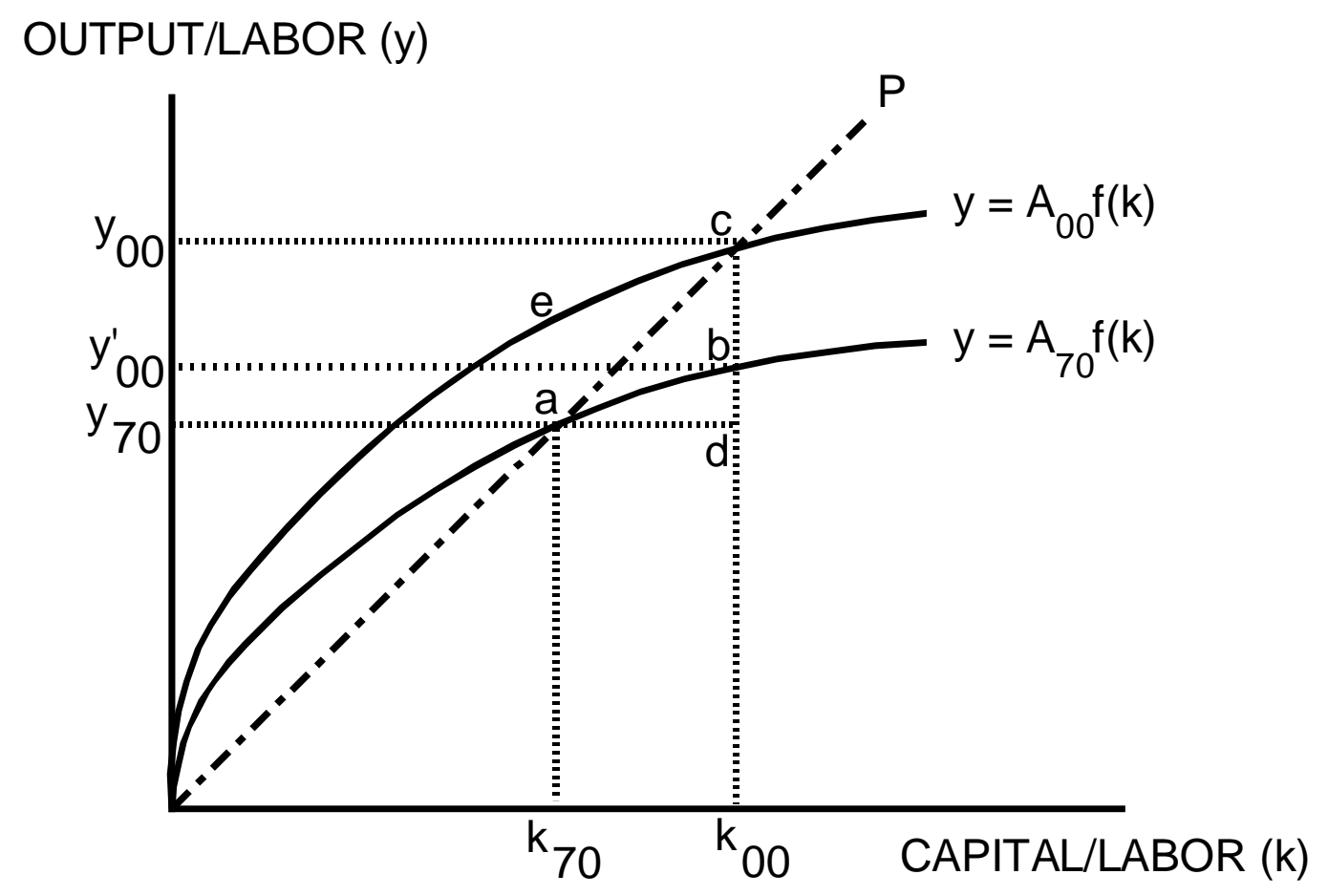


Figure 2. Output per Worker, by Meta Country, 1970-2000

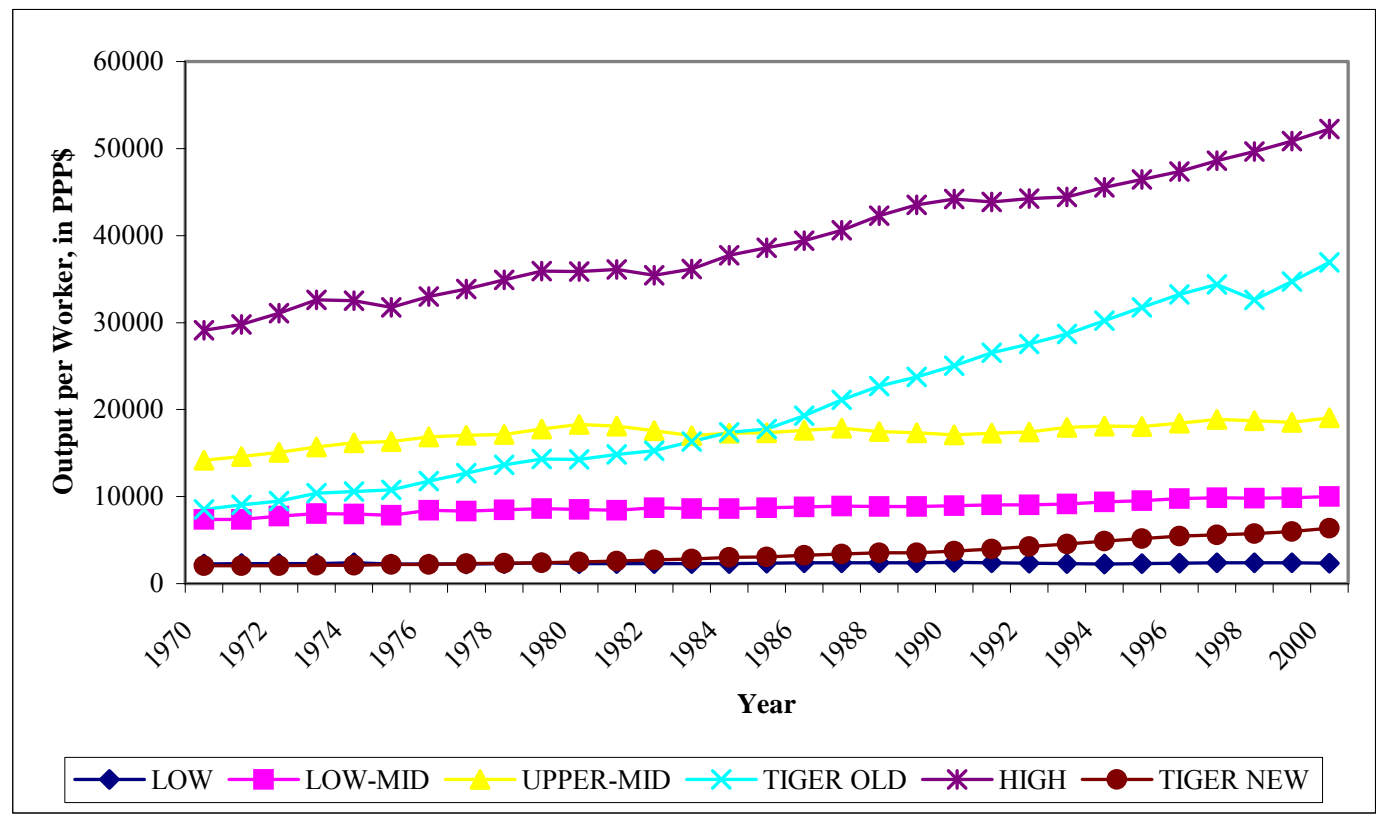


Figure 3. TFP Levels Relative to High Income, CCD Method, OECD $=1.00$

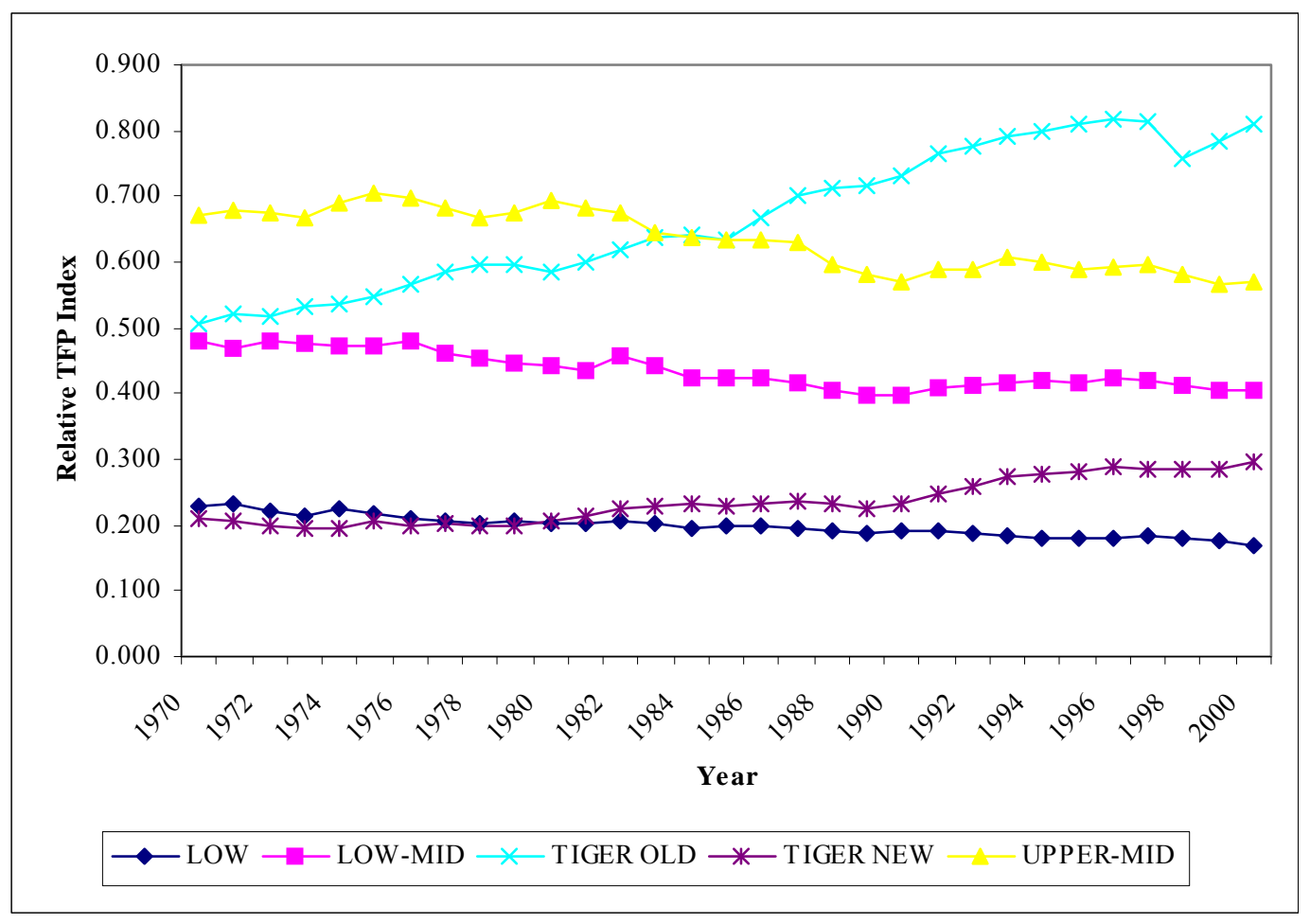




\section{Data Appendix}

Table A.1. Basic Statistics and Countries, Organized by Meta Country

\begin{tabular}{|c|c|c|c|c|c|c|c|c|c|c|c|}
\hline HIGH INCOME & $\begin{array}{c}\text { DPOP } \\
1970-2000\end{array}$ & $\begin{array}{c}\text { Y/L } \\
1970 \\
\end{array}$ & $\begin{array}{c}\text { Y/L } \\
2000\end{array}$ & $\begin{array}{c}\text { DY/L } \\
1970-2000\end{array}$ & $\begin{array}{c}I / Y \\
1970-2000\end{array}$ & $\begin{array}{l}K / L \\
1970\end{array}$ & $\begin{array}{l}K / L \\
2000\end{array}$ & $\begin{array}{c}\text { DK/L } \\
1970-2000\end{array}$ & $\begin{array}{c}\text { Y/POP } \\
1970 \\
\end{array}$ & $\begin{array}{c}\text { Y/POP } \\
2000\end{array}$ & $\begin{array}{c}\text { DY/POP } \\
1970-2000 \\
\end{array}$ \\
\hline Australia & 0.013 & 34747 & 51568 & 0.013 & 0.238 & 86703 & 148660 & 0.017 & 14820 & 25559 & 0.018 \\
\hline Austria & 0.003 & 26736 & 50591 & 0.021 & 0.260 & 66469 & 169797 & 0.030 & 11176 & 23676 & 0.024 \\
\hline Belgium & 0.002 & 32427 & 56752 & 0.018 & 0.231 & 81200 & 176457 & 0.025 & 12143 & 23781 & 0.022 \\
\hline Canada & 0.012 & 34692 & 52295 & 0.013 & 0.228 & 61994 & 152421 & 0.029 & 14102 & 26904 & 0.021 \\
\hline Cyprus & 0.008 & 12603 & 39218 & 0.037 & 0.249 & 34347 & 92786 & 0.032 & 5275 & 17742 & 0.039 \\
\hline Denmark & 0.003 & 33218 & 48255 & 0.012 & 0.229 & 83723 & 151198 & 0.019 & 16038 & 26608 & 0.016 \\
\hline Finland & 0.004 & 23899 & 47281 & 0.022 & 0.260 & 64823 & 145963 & 0.026 & 11412 & 23792 & 0.024 \\
\hline France & 0.005 & 28960 & 49136 & 0.017 & 0.246 & 65718 & 160775 & 0.029 & 12336 & 22358 & 0.019 \\
\hline Greece & 0.006 & 21755 & 33783 & 0.014 & 0.247 & 50713 & 103785 & 0.023 & 8441 & 14614 & 0.018 \\
\hline Iceland & 0.010 & 25205 & 45055 & 0.019 & 0.258 & 77138 & 138571 & 0.019 & 10925 & 24777 & 0.026 \\
\hline Ireland & 0.008 & 19079 & 65054 & 0.040 & 0.192 & 28880 & 115744 & 0.045 & 7260 & 26381 & 0.042 \\
\hline Israel & 0.024 & 24021 & 38762 & 0.015 & 0.271 & 54458 & 113059 & 0.024 & 8837 & 16954 & 0.021 \\
\hline Italy & 0.002 & 28883 & 53949 & 0.020 & 0.233 & 74156 & 169291 & 0.027 & 11294 & 21780 & 0.021 \\
\hline Japan & 0.007 & 18098 & 38737 & 0.025 & 0.322 & 34551 & 161357 & 0.050 & 11474 & 24675 & 0.025 \\
\hline Luxembourg & 0.008 & 39277 & 103133 & 0.031 & 0.225 & 115514 & 243753 & 0.024 & 15121 & 43989 & 0.034 \\
\hline Netherlands & 0.006 & 33112 & 52230 & 0.015 & 0.234 & 84187 & 152928 & 0.019 & 13320 & 24313 & 0.019 \\
\hline New Zealand & 0.010 & 35083 & 39360 & 0.004 & 0.211 & 78165 & 115780 & 0.013 & 13665 & 18816 & 0.010 \\
\hline Norway & 0.005 & 27024 & 54032 & 0.022 & 0.318 & 91446 & 200385 & 0.025 & 11188 & 27060 & 0.028 \\
\hline Portugal & 0.004 & 14823 & 35008 & 0.028 & 0.213 & 25056 & 96372 & 0.043 & 6296 & 15923 & 0.030 \\
\hline Spain & 0.005 & 23675 & 44113 & 0.020 & 0.242 & 47853 & 134732 & 0.033 & 9076 & 18047 & 0.022 \\
\hline Sweden & 0.003 & 31990 & 45453 & 0.011 & 0.213 & 79456 & 133786 & 0.017 & 14828 & 23635 & 0.015 \\
\hline Switzerland & 0.004 & 43346 & 47412 & 0.003 & 0.266 & 129962 & 192283 & 0.013 & 20611 & 26414 & 0.008 \\
\hline UK & 0.002 & 26272 & 44649 & 0.017 & 0.181 & 58109 & 113065 & 0.021 & 12085 & 22190 & 0.020 \\
\hline USA & 0.010 & 38432 & 64537 & 0.017 & 0.197 & 60506 & 161391 & 0.032 & 16351 & 33293 & 0.023 \\
\hline AVERAGE & 0.007 & 29108 & 52211 & 0.020 & 0.240 & 57171 & 154321 & 0.033 & 13290 & 26595 & 0.023 \\
\hline
\end{tabular}

LOW INCOME (up to YPOP 3,000 in year 2000)

\begin{tabular}{|c|c|c|c|c|c|c|c|c|c|c|c|}
\hline Angola & 0.023 & 5767 & 3050 & -0.021 & 0.075 & 4223 & 3428 & -0.007 & 3329 & 1612 & -0.023 \\
\hline Bangladesh & 0.022 & 2243 & 3187 & 0.011 & 0.098 & 3193 & 3707 & 0.005 & 1105 & 1684 & 0.014 \\
\hline Benin & 0.028 & 2041 & 2489 & 0.006 & 0.074 & 816 & 2079 & 0.030 & 1094 & 1214 & 0.003 \\
\hline Bolivia & 0.022 & 6036 & 6829 & 0.004 & 0.094 & 8409 & 9053 & 0.002 & 2498 & 2724 & 0.003 \\
\hline Burkina Faso & 0.022 & 1159 & 1939 & 0.017 & 0.099 & 717 & 2509 & 0.040 & 669 & 957 & 0.012 \\
\hline Burundi & 0.021 & 1467 & 990 & -0.013 & 0.057 & 326 & 1028 & 0.037 & 848 & 523 & -0.016 \\
\hline Cameroon & 0.026 & 2552 & 4125 & 0.015 & 0.078 & 1445 & 3981 & 0.033 & 1580 & 2042 & 0.008 \\
\hline Central African Rep. & 0.022 & 3964 & 2144 & -0.020 & 0.045 & 2529 & 1959 & -0.008 & 2240 & 1045 & -0.025 \\
\hline Chad & 0.024 & 2352 & 1837 & -0.008 & 0.089 & 4196 & 2285 & -0.020 & 1180 & 909 & -0.008 \\
\hline Comoros & 0.024 & 4811 & 3498 & -0.010 & 0.078 & 3005 & 4090 & 0.010 & 2353 & 1578 & -0.013 \\
\hline Congo & 0.028 & 1612 & 3686 & 0.027 & 0.173 & 4476 & 4968 & 0.003 & 929 & 1808 & 0.021 \\
\hline Cote d'Ivoire & 0.034 & 4823 & 4679 & -0.001 & 0.076 & 3547 & 4179 & 0.005 & 2391 & 1869 & -0.008 \\
\hline DR Congo & 0.029 & 1835 & 252 & -0.064 & 0.052 & 702 & 636 & -0.003 & 1056 & 118 & -0.071 \\
\hline Ethiopia & 0.026 & 1293 & 1483 & 0.004 & 0.041 & 763 & 787 & 0.001 & 608 & 635 & 0.001 \\
\hline Gambia & 0.033 & 2104 & 2393 & 0.004 & 0.064 & 451 & 2044 & 0.049 & 1113 & 1217 & 0.003 \\
\hline Ghana & 0.026 & 2277 & 2775 & 0.006 & 0.073 & 3091 & 2360 & -0.009 & 1282 & 1351 & 0.002 \\
\hline Guinea & 0.021 & 4304 & 5977 & 0.011 & 0.113 & 10496 & 7794 & -0.010 & 2282 & 2831 & 0.007 \\
\hline Guinea Bissau & 0.027 & 577 & 1287 & 0.026 & 0.206 & 2628 & 2859 & 0.003 & 332 & 688 & 0.024 \\
\hline Haiti & 0.017 & 1827 & 5569 & 0.036 & 0.051 & 523 & 1834 & 0.040 & 930 & 2416 & 0.031 \\
\hline Honduras & 0.029 & 5608 & 5415 & -0.001 & 0.127 & 6318 & 10234 & 0.016 & 1861 & 2050 & 0.003 \\
\hline Kenya & 0.031 & 1450 & 2476 & 0.017 & 0.108 & 2072 & 2743 & 0.009 & 821 & 1244 & 0.013 \\
\hline Lesotho & 0.021 & 1730 & 3365 & 0.021 & 0.189 & 536 & 10260 & 0.095 & 883 & 1592 & 0.019 \\
\hline
\end{tabular}




\begin{tabular}{|c|c|c|c|c|c|c|c|c|c|c|c|}
\hline LOW INCOME & $\begin{array}{c}\text { DPOP } \\
1970-2000 \\
\end{array}$ & $\begin{array}{c}\mathrm{Y} / \mathrm{L} \\
1970 \\
\end{array}$ & $\begin{array}{c}\mathbf{Y} / \mathbf{L} \\
2000 \\
\end{array}$ & $\begin{array}{c}\text { DY/L } \\
1970-2000 \\
\end{array}$ & $\begin{array}{c}I / Y \\
1970-2000 \\
\end{array}$ & $\begin{array}{l}\mathrm{K} / \mathrm{L} \\
1970 \\
\end{array}$ & $\begin{array}{l}K / L \\
2000\end{array}$ & $\begin{array}{c}\text { DK/L } \\
1970-2000 \\
\end{array}$ & $\begin{array}{c}\text { Y/POP } \\
1970 \\
\end{array}$ & $\begin{array}{c}\text { Y/POP } \\
2000 \\
\end{array}$ & $\begin{array}{c}\text { DY/POP } \\
1970-2000 \\
\end{array}$ \\
\hline Madagascar & 0.026 & 2546 & 1772 & -0.012 & 0.028 & 896 & 741 & -0.006 & 1274 & 836 & -0.014 \\
\hline Malawi & 0.027 & 871 & 1631 & 0.020 & 0.138 & 1337 & 1722 & 0.008 & 455 & 784 & 0.018 \\
\hline Mali & 0.023 & 1485 & 2033 & 0.010 & 0.075 & 1812 & 1896 & 0.001 & 784 & 969 & 0.007 \\
\hline Mauritania & 0.024 & 3397 & 2912 & -0.005 & 0.067 & 761 & 2892 & 0.043 & 1881 & 1447 & -0.008 \\
\hline Mozambique & 0.020 & 2807 & 2000 & -0.011 & 0.027 & 615 & 875 & 0.011 & 1571 & 1037 & -0.013 \\
\hline Nepal & 0.023 & 1511 & 3144 & 0.024 & 0.135 & 824 & 5028 & 0.058 & 816 & 1459 & 0.019 \\
\hline Nicaragua & 0.028 & 12280 & 4367 & -0.033 & 0.117 & 10451 & 9274 & -0.004 & 3980 & 1767 & -0.026 \\
\hline Niger & 0.031 & 2653 & 1823 & -0.012 & 0.073 & 2052 & 1501 & -0.010 & 1519 & 875 & -0.018 \\
\hline Nigeria & 0.028 & 1997 & 1479 & -0.010 & 0.089 & 781 & 2383 & 0.036 & 1113 & 707 & -0.015 \\
\hline Papua New Guinea & 0.023 & 5247 & 5924 & 0.004 & 0.124 & 6473 & 9592 & 0.013 & 2862 & 2866 & 0.000 \\
\hline Rwanda & 0.027 & 1676 & 1786 & 0.002 & 0.039 & 325 & 971 & 0.035 & 887 & 895 & 0.000 \\
\hline Senegal & 0.027 & 2949 & 3389 & 0.004 & 0.072 & 2758 & 2977 & 0.002 & 1627 & 1622 & 0.000 \\
\hline Sierra Leone & 0.021 & 3649 & 1910 & -0.021 & 0.033 & 645 & 1468 & 0.026 & 1496 & 695 & -0.025 \\
\hline Tanzania, U. Rep. of & 0.029 & 1056 & 938 & -0.004 & 0.243 & 2356 & 2405 & 0.001 & 565 & 482 & -0.005 \\
\hline Togo & 0.026 & 3109 & 2149 & -0.012 & 0.078 & 1129 & 2784 & 0.029 & 1397 & 870 & -0.015 \\
\hline Uganda & 0.026 & 1144 & 1835 & 0.015 & 0.023 & 161 & 537 & 0.039 & 608 & 941 & 0.014 \\
\hline Zambia & 0.028 & 2946 & 2141 & -0.010 & 0.169 & 8255 & 4457 & -0.020 & 1335 & 892 & -0.013 \\
\hline Zimbabwe & 0.028 & 3723 & 5127 & 0.010 & 0.199 & 9226 & 10738 & 0.005 & 2155 & 2486 & 0.005 \\
\hline AVERAGE & 0.026 & 2239 & 2359 & 0.002 & 0.095 & 2142 & 2843 & 0.009 & 1176 & 1138 & -0.001 \\
\hline
\end{tabular}

\section{LOW-MID (from YPOP 3,001 to YPOP 6,000 in year 2000)}

$\begin{array}{lccccccccccc}\text { Algeria } & 0.026 & 13369 & 14527 & 0.003 & 0.190 & 16093 & 29706 & 0.020 & 3433 & 4896 & 0.011 \\ \text { Cape Verde } & 0.016 & 4061 & 10078 & 0.029 & 0.171 & 4652 & 15448 & 0.039 & 1387 & 4027 & 0.034 \\ \text { Colombia } & 0.020 & 7651 & 11477 & 0.013 & 0.116 & 7860 & 16847 & 0.025 & 3159 & 5383 & 0.017 \\ \text { Costa Rica } & 0.025 & 13639 & 14827 & 0.003 & 0.151 & 13398 & 26203 & 0.022 & 4181 & 5870 & 0.011 \\ \text { Dominican Republic } & 0.021 & 7488 & 16173 & 0.025 & 0.138 & 6156 & 20717 & 0.039 & 2018 & 5270 & 0.031 \\ \text { Ecuador } & 0.024 & 7069 & 9023 & 0.008 & 0.189 & 16442 & 22049 & 0.009 & 2292 & 3468 & 0.013 \\ \text { Egypt } & 0.021 & 5603 & 10970 & 0.022 & 0.076 & 2553 & 7379 & 0.034 & 1970 & 4184 & 0.024 \\ \text { El Salvador } & 0.018 & 12578 & 10368 & -0.006 & 0.072 & 7532 & 10390 & 0.010 & 4141 & 4435 & 0.002 \\ \text { Equatorial Guinea } & 0.015 & 8094 & 8641 & 0.002 & 0.130 & 3091 & 15860 & 0.053 & 3758 & 3604 & -0.001 \\ \text { Fiji } & 0.014 & 11620 & 13580 & 0.005 & 0.147 & 19314 & 24384 & 0.008 & 3433 & 4971 & 0.012 \\ \text { Guatemala } & 0.025 & 8673 & 10611 & 0.007 & 0.081 & 6972 & 10314 & 0.013 & 2991 & 3914 & 0.009 \\ \text { Guyana } & 0.002 & 8628 & 8243 & -0.001 & 0.163 & 23071 & 18465 & -0.007 & 2432 & 3532 & 0.012 \\ \text { Iran } & 0.026 & 18304 & 19560 & 0.002 & 0.197 & 17202 & 38541 & 0.026 & 5225 & 5995 & 0.004 \\ \text { Jamaica } & 0.011 & 10177 & 7310 & -0.011 & 0.173 & 24743 & 21030 & -0.005 & 3867 & 3693 & -0.001 \\ \text { Jordan } & 0.038 & 8120 & 13087 & 0.015 & 0.146 & 6841 & 21156 & 0.036 & 2228 & 3895 & 0.018 \\ \text { Morocco } & 0.020 & 6815 & 9301 & 0.010 & 0.139 & 5460 & 14654 & 0.032 & 2261 & 3717 & 0.016 \\ \text { Namibia } & 0.025 & 13955 & 14689 & 0.002 & 0.182 & 26608 & 28559 & 0.002 & 4770 & 4529 & -0.002 \\ \text { Pakistan } & 0.027 & 2729 & 5360 & 0.022 & 0.117 & 4024 & 6412 & 0.015 & 943 & 2008 & 0.024 \\ \text { Paraguay } & 0.027 & 6183 & 10439 & 0.017 & 0.121 & 3930 & 15810 & 0.045 & 2874 & 4684 & 0.016 \\ \text { Peru } & 0.021 & 11927 & 10095 & -0.005 & 0.170 & 26080 & 25698 & 0.000 & 4686 & 4589 & -0.001 \\ \text { Philippines } & 0.023 & 6548 & 8374 & 0.008 & 0.152 & 8197 & 15312 & 0.020 & 2396 & 3425 & 0.012 \\ \text { Sri Lanka } & 0.014 & 3745 & 7646 & 0.023 & 0.119 & 2090 & 10726 & 0.053 & 1557 & 3300 & 0.024 \\ \text { AVERAGE } & \mathbf{0 . 0 2 4} & \mathbf{7 3 7 4} & \mathbf{9 9 8 4} & \mathbf{0 . 0 1 0} & \mathbf{0 . 1 4 3} & \mathbf{8 4 1 7} & \mathbf{1 5 8 3 5} & \mathbf{0 . 0 2 1} & \mathbf{2 5 6 0} & \mathbf{3 8 4 6} & \mathbf{0 . 0 1 3}\end{array}$

UPPER-MID (from YPOP 6,001 and above in year 2000, excluding OECD + Israel)

$\begin{array}{lccccccccccc}\text { Argentina } & 0.014 & 19967 & 25670 & 0.008 & 0.173 & 37276 & 58223 & 0.014 & 9265 & 11006 & 0.006 \\ \text { Barbados } & 0.004 & 15935 & 32961 & 0.023 & 0.148 & 31065 & 41302 & 0.009 & 6040 & 16415 & 0.032 \\ \text { Botswana } & 0.029 & 3126 & 23926 & 0.066 & 0.188 & 2896 & 32356 & 0.078 & 1193 & 8241 & 0.062 \\ \text { Brazil } & 0.019 & 11006 & 19220 & 0.018 & 0.207 & 18028 & 43954 & 0.029 & 3620 & 7190 & 0.022 \\ \text { Chile } & 0.015 & 15345 & 25084 & 0.016 & 0.151 & 25676 & 49286 & 0.021 & 4794 & 9926 & 0.023 \\ \text { Gabon } & 0.029 & 11293 & 17645 & 0.014 & 0.140 & 8597 & 23958 & 0.033 & 6857 & 8402 & 0.007 \\ \text { Mauritius } & 0.012 & 13162 & 32241 & 0.029 & 0.126 & 13700 & 39386 & 0.034 & 4005 & 13932 & 0.040 \\ \text { Mexico } & 0.022 & 17965 & 21111 & 0.005 & 0.182 & 27956 & 46815 & 0.017 & 5522 & 8762 & 0.015\end{array}$




\begin{tabular}{|c|c|c|c|c|c|c|c|c|c|c|c|}
\hline UPPER-MID & $\begin{array}{c}\text { DPOP } \\
1970-2000\end{array}$ & $\begin{array}{c}\mathrm{Y} / \mathrm{L} \\
1970\end{array}$ & $\begin{array}{c}\text { Y/L } \\
2000\end{array}$ & $\begin{array}{c}\text { DY/L } \\
1970-2000\end{array}$ & $\begin{array}{c}\text { I/Y } \\
1970-2000\end{array}$ & $\begin{array}{l}\mathrm{K} / \mathrm{L} \\
1970\end{array}$ & $\begin{array}{l}K / L \\
2000\end{array}$ & $\begin{array}{c}\text { DK/L } \\
1970-2000\end{array}$ & $\begin{array}{c}\text { Y/POP } \\
1970 \\
\end{array}$ & $\begin{array}{c}\text { Y/POP } \\
2000 \\
\end{array}$ & $\begin{array}{c}\text { DY/POP } \\
1970-2000 \\
\end{array}$ \\
\hline Panama & 0.021 & 11357 & 14382 & 0.008 & 0.207 & 17391 & 37650 & 0.025 & 3824 & 6066 & 0.015 \\
\hline Seychelles & 0.013 & 8470 & 23552 & 0.033 & 0.149 & 4934 & 44543 & 0.071 & 4091 & 10241 & 0.030 \\
\hline South Africa & 0.021 & 18415 & 18488 & 0.000 & 0.120 & 23582 & 25070 & 0.002 & 6878 & 7541 & 0.003 \\
\hline Syria & 0.031 & 26235 & 28817 & 0.003 & 0.190 & 34728 & 14163 & -0.029 & 7542 & 9193 & 0.006 \\
\hline Trinidad and Tobago & 0.009 & 19842 & 25188 & 0.008 & 0.106 & 13058 & 33090 & 0.030 & 6582 & 11175 & 0.017 \\
\hline Tunisia & 0.020 & 8573 & 17124 & 0.022 & 0.160 & 20720 & 26610 & 0.008 & 2568 & 6776 & 0.031 \\
\hline Turkey & 0.020 & 8017 & 14125 & 0.018 & 0.162 & 8040 & 29528 & 0.042 & 3619 & 6832 & 0.021 \\
\hline Uruguay & 0.006 & 13579 & 21150 & 0.014 & 0.121 & 19073 & 34882 & 0.019 & 6131 & 9622 & 0.015 \\
\hline Venezuela & 0.026 & 35399 & 15705 & -0.026 & 0.168 & 44808 & 36511 & -0.007 & 10528 & 6420 & -0.016 \\
\hline AVERAGE & 0.020 & 14566 & 19492 & 0.009 & 0.159 & 22076 & 40132 & 0.019 & 5184 & 7924 & 0.014 \\
\hline $\begin{array}{l}\text { OLD TIGERS } \\
\text { Hong Kong, SAR of } \\
\text { China }\end{array}$ & 0.018 & 15587 & 51469 & 0.039 & 0.249 & 28329 & 138086 & 0.051 & 6506 & 26699 & 0.046 \\
\hline Korea, Republic of & 0.012 & 7676 & 31239 & 0.045 & 0.311 & 9584 & 98424 & 0.075 & 2716 & 15876 & 0.057 \\
\hline Singapore & 0.021 & 15085 & 50809 & 0.039 & 0.454 & 32892 & 187383 & 0.056 & 5279 & 28869 & 0.055 \\
\hline Taiwan, P. of China & 0.013 & 7282 & 42402 & 0.057 & 0.194 & 6392 & 78537 & 0.081 & 2790 & 19034 & 0.062 \\
\hline AVERAGE & 0.013 & 8513 & 36922 & 0.048 & 0.302 & 11132 & 102174 & 0.074 & 3120 & 18312 & 0.059 \\
\hline \multicolumn{12}{|l|}{ NEW TIGERS } \\
\hline China & 0.014 & 1583 & 6175 & 0.044 & 0.178 & 1564 & 10624 & 0.062 & 815 & 3747 & 0.049 \\
\hline India & 0.020 & 2454 & 5587 & 0.027 & 0.118 & 2470 & 6729 & 0.032 & 1073 & 2479 & 0.027 \\
\hline Indonesia & 0.019 & 2865 & 7677 & 0.032 & 0.146 & 1635 & 13772 & 0.069 & 1087 & 3642 & 0.039 \\
\hline Malaysia & 0.025 & 8377 & 23994 & 0.034 & 0.223 & 10090 & 54710 & 0.055 & 2884 & 9919 & 0.040 \\
\hline Thailand & 0.017 & 3758 & 11308 & 0.036 & 0.309 & 7486 & 36890 & 0.051 & 1822 & 6857 & 0.043 \\
\hline AVERAGE & 0.017 & 2036 & 6355 & 0.037 & 0.195 & 2052 & 10587 & 0.054 & 966 & 3367 & 0.041 \\
\hline
\end{tabular}

Note: The averages have been computed based on the meta-country averages. For example, output per worker in 2000 has been obtained by first summing income and workers separately for a given meta country, thereafter dividing total income with total workers and then dividing this ratio by the number of countries. An alternative way, leading to a slightly different result, is to first compute income per worker for each country, sum the country results and then divide this total by the number of countries.

DPOP = Average annual growth rate (AAGR) of population; $\mathbf{Y} / \mathbf{L}=$ GDP per worker; DY/L = AAGR of GDP per worker; $\mathbf{I} / \mathbf{Y}=$ Investment share in GDP; $\mathbf{K} / \mathbf{L}=$ capital-labor ratio; $\mathbf{D K} / \mathbf{L}=$ AAGR of capital-labor ratio (i.e. capital deepening); Y/POP = GDP per capita; and DY/POP = AAGR of GDP per capita. 


\section{Capital stocks}

We use a perpetual inventory method (PIM) to estimate the stock of capital from the investment data (the capital stock is denoted $\mathrm{K} 05+\mathrm{S}$ in Figure A.1.). Under the PIM, the stock of capital at the end of year $t$ that is available for production in the following year, $K_{t+1}$, is equal to the depreciated amount of capital left over from the preceding year, $(1-\delta) K_{t}$, plus the amount of new capital added through investment during the year, $I_{t}$ :

$$
K_{t+1}=(1-\delta) K_{t}+I_{t},
$$

The $\delta$ denotes the depreciation rate here, as in the text. By substituting backward in time to some initial period, equation A.1 can be expressed in terms of the depreciated stream of investment plus the initial capital stock, $K_{0}$ :

$$
K_{t}=(1-\delta)^{t} K_{0}+\sum_{i=1}^{t}(1-\delta)^{t-i} I_{i}
$$

This method of estimating the stock of capital requires time-series data on real investment, which we obtain from the Penn World Tables 6.1 (Heston, Summers and Aten, 2002), in purchasing power parity 1996 US dollars. We have no information as to country-specific depreciation rates, so we assume a common 5 percent rate for each country.

To obtain a starting value for the capital stock of each country, we assume the country is at its steady state capital-output ratio. The steady-state benchmark value is obtained from the equation:

$$
k=i /(g+\delta),
$$

where $k=\mathrm{K} / \mathrm{Y}$ (i.e. capital-output ratio), $g=$ the growth rate of real Y (i.e. growth of GDP), and $i$ $=\mathrm{I} / \mathrm{Y}$ (i.e. investment rate). The steady-state growth of GDP $(g)$ and the investment rate $(i)$, respectively, are calculated as the annual average over 10 years (1960-1969). Inserting these into (A.3) gives $k$ and the benchmark is obtained by multiplying $k$ by initial GDP. Thereafter, we add 10 years of investment to the benchmark and this marks the initial capital stock, $K_{0}$.

We have also investigated the robustness of this procedure against two other computational methods. The first alternative is to use the steady-state approach discussed above to compute the initial capital stock, $K_{1970}$, and thereafter apply the perpetual inventory method to the remaining years (KS). Our second procedure is to use the perpetual inventory method, but this time without the steady-state approach to obtaining a benchmark, i.e. the benchmark is zero in 1960. The accumulation of 10 years of investment is then taken to represent the initial capital stock in 1970 (K05).

Figure A.1 shows how the three capital stocks actually tend to converge over time and this leads us to have faith in our choice of calculating capital stock, implying a reasonably high degree of robustness to our method of estimating the initial level of capital. 
Figure A.1. Capital Stocks Under Three Assumptions.

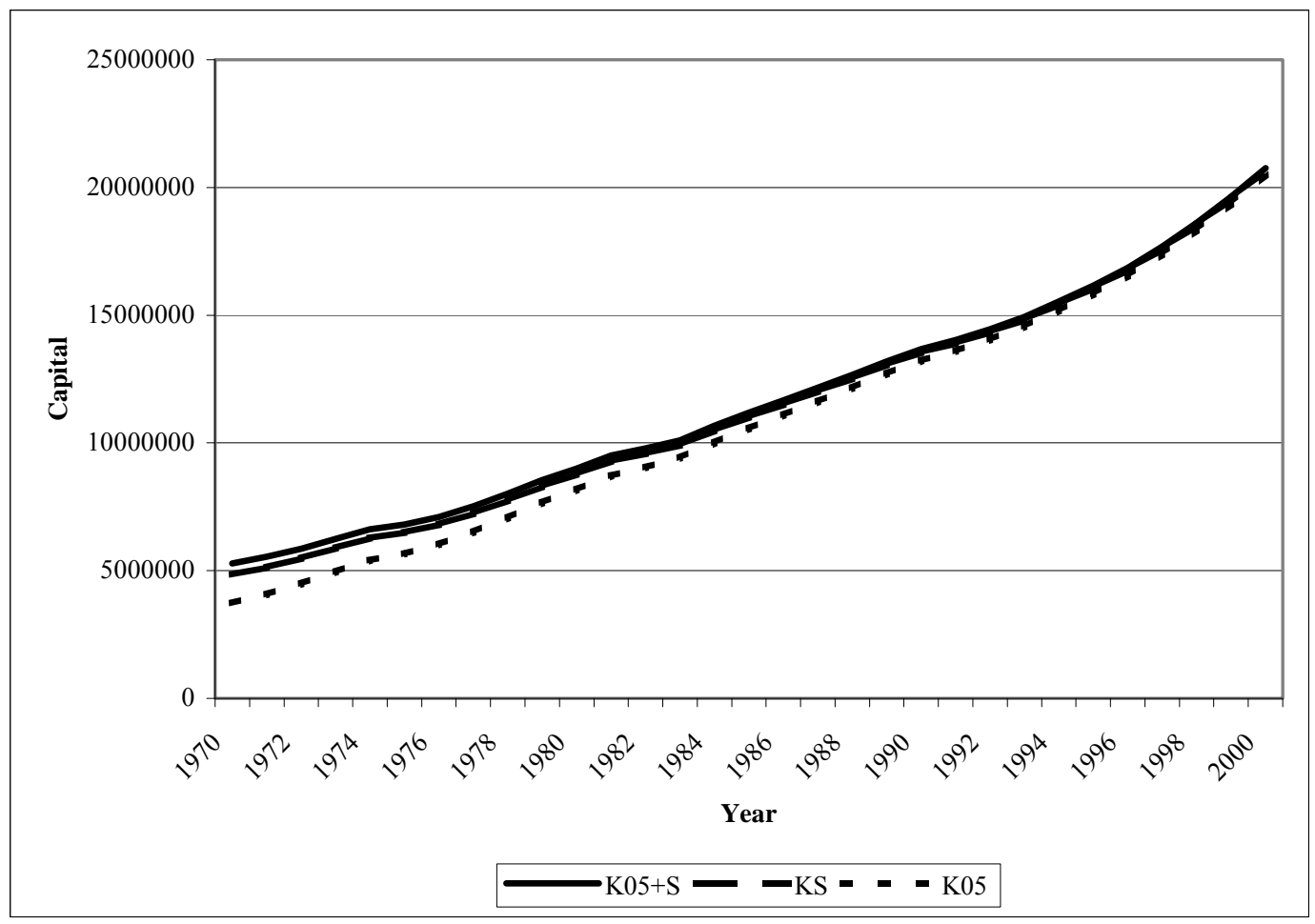

Table A.2. Comparison of Capital Stocks Based on PPP (\$) and National Prices (\$).

\begin{tabular}{|c|c|c|c|}
\hline \multicolumn{3}{|c|}{ PPP, \$ } & National prices, $\$$ \\
\hline Meta-countries & AAGR & Meta-countries & AAGR \\
\hline Low & 0.61 & Low & 0.85 \\
\hline Low-Mid & 1.94 & Low-Mid & 1.90 \\
\hline Upper-Mid & 1.70 & Upper-Mid & 1.47 \\
\hline Old Tigers & 7.12 & Old Tigers & 6.84 \\
\hline New Tigers & 5.44 & New Tigers & 5.16 \\
\hline High & 3.30 & High & 2.53 \\
\hline
\end{tabular}

AAGR = Average annual growth rates in percent for the period 1970-2000.

Note: The difference between the two columns, when multiplied by .33, gives the change in TFP growth rates in Table 1a that would occur if national prices were substituted for PPP prices. 


\section{Labor shares}

It is standard in cross-country analysis to assume common labor shares across countries, with a two-thirds share commonly assigned to labor (Gollin (2002)). However, the labor shares are calculated from published data reveal very large differences across countries. ${ }^{16}$ Figure A.2 reveals just how large the differences are, and how far short of the two-thirds share the actual estimates are. In general, labor shares increase with income level of the meta country, although they remain fairly constant within meta countries.

Figure A.2. Labor's Income Share for 6 Meta-Countries

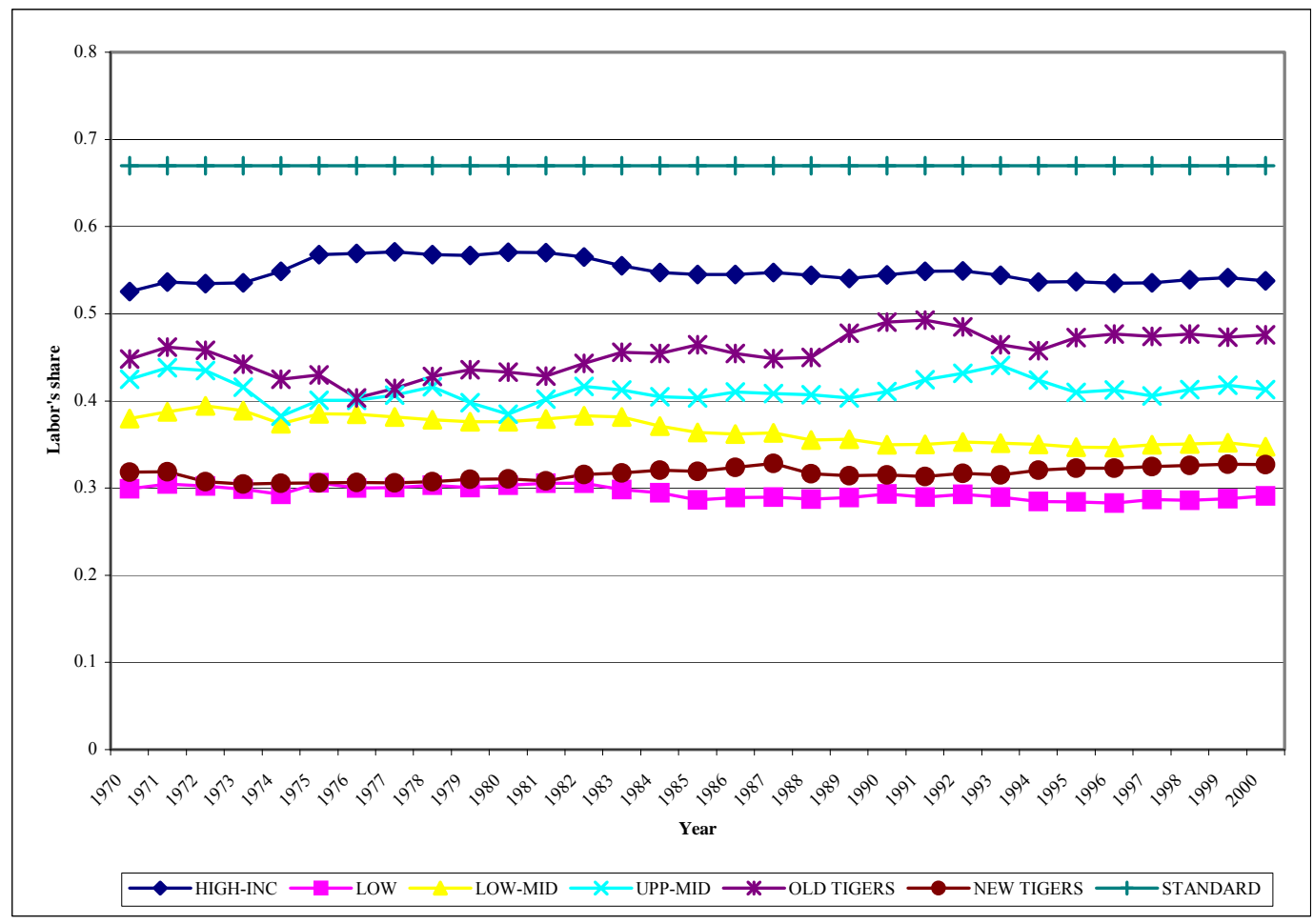

${ }^{16}$ Data on labor shares are not available for all countries. The average labor shares are therefore based on meta countries excluding the following countries: HIGH Cyprus; LOW Bangladesh, Comoros, D.R. Congo, Ethiopia, Gambia, Guinea and Nepal; LOW-MID Cape Verde, El Salvador, Equatorial Guinea, Guatemala, Pakistan and Syria; NEW TIGERS Indonesia. 